\title{
ÚLTIMOS AZOTES: EL ARTE DE SERMONES DE MARTÍN DE VELASCO A LA LUZ DE LA POLÉMICA ORMAZA / CÉSPEDES
}

\author{
Rafael Bonilla Cerezo \\ Universidad de Córdoba
}

Siete lustros antes de que José de Ormaza -bajo la máscara de Gonzalo Pérez de Ledesma- diera a luz su Censura de la elocuencia (Zaragoza, 1648), arte retórica que supuso para la predicación un alboroto similar a la riada de antídotos y pareceres que motivaron las Soledades de Góngora en la poesía, Cervantes fantaseaba con dos alanos en posesión no solo del divino don del habla, sino de la agudeza para cuestionar a quienes, en principio, mejor hacían gala de facundia:

CIPIón.- Y decías muy bien, Berganza, porque no hay mayor ni más sotil ladrón que el doméstico, y así, mueren muchos más de los confiados que de los recatados; pero el daño está en que es imposible que puedan pasar bien las gentes en el mundo si no se fía y se confía. Mas quédese aquí esto, que no quiero que parezcamos predicadores. Pasa adelante. ${ }^{1}$

\footnotetext{
1 M. de Cervantes, Novelas ejemplares, ed. H. Sieber, Madrid, Cátedra, 1980, II, p. 311.
} 
Aquella ladina glosa del perrillo sobre el afán suasorio y la verbosidad de los ministros de la Iglesia nos guía hasta otro par de cínicos que dialogaron, in absentia, con un paréntesis editorial de veintiún años arbitrando su mutuo desprecio, acerca de la función artística -e incluso devota- de los sermones. Más allá de los ensayos de Herrero-García ${ }^{2}$ y Dansey Smith, ${ }^{3}$ de los trabajos de Francis Cerdan a propósito de Paravicino y de su bibliografía en el monográfico que coordinó para la revista Criticón ${ }^{4}$ no es que nos topemos con el capítulo peor conocido de la prosa áurea -ahí están las ediciones de Ledda y Stagno, ${ }^{5}$ el propio Cerdan y Laplana ${ }^{6}$ y Soria Ortega ${ }^{7}-$, sino que hemos orillado a varios epígonos de la polémica Ormaza vs. Céspedes: el rosario de voces que avivó aquel debate entre jesuitas desde 1669 a 1700. Más cabalmente: desde la impresión de Trece por docena (1669), del Padre Céspedes, escrito hacia 1649-1651, hasta el ocaso del Barroco.

$\mathrm{Ni}$ siquiera los especialistas han mostrado mucho interés por esta «coda homilética». Cerdan, apoyándose en Herrero-García, dividió el género en cuatro ciclos, previos a las plumas que nos ocupan: a) la época heroica (Juan de Ávila y fray Luis de Granada); b) la Edad de Oro, que abarca gran parte del reinado de Felipe III y conoce la eclosión de muchos autores de primera categoría, perfectamente equilibrados entre la profundidad de la doctrina y la elegancia del estilo; c) el magisterio de Paravicino (1615-1633), caracterizado por un registro más culto que ocasionó terribles resistencias y luchas literarias; ${ }^{8}$ d) los treinta años (1633-1664) desde la muerte de fray Hortensio hasta el fin de la monarquía de Felipe IV. Triunfaron entonces «todas las tendencias

2 M. Herrero-García, Sermonario clásico, Madrid / Buenos Aires, Escelicer, 1942.

3 H. D. Smith, Preaching in the Spanish Golden Age, Oxford, University Press, 1978.

4 F. Cerdan, Études sur Fray Hortensio Paravicino et la prédication de son temps, Presses Universitaires du Septentrion, 1994; Fray Hortensio Paravicino. Prédicateur poète (1580-1633), Presses Universitaires du Septentrion, 1994; «Actualidad de los estudios sobre oratoria sagrada del Siglo de Oro (1985-2002). Balance y perspectivas», Criticón, 84/85. La oratoria sagrada en el Siglo de Oro, ed. F. Cerdan, Presses Universitaires du Mirail (2002), pp. 9-42. Véase también M. Á. Núñez Beltrán, La oratoria sagrada de la época del barroco. Doctrina, cultura y actitud ante la vida desde los sermones sevillanos del siglo XVII, Sevilla, Universidad de Sevilla, Fundación Focus Abengoa, 2000.

5 G. Pérez de Ledesma, Censura de la elocuencia (Zaragoza, 1648), introd. G. Ledda y texto de G. Ledda y V. Stagno, Madrid, Anejos de El Crotalón, 1985. Alterno por variatio de estilo el nombre real (Ormaza), su seudónimo (Pérez de Ledesma) y el mote que le asigna Céspedes: «el Censor».

6 V. de Céspedes s. j. (alias Juan de la Encina), Trece por docena, edición, introducción y notas de F. Cerdan y J. E. Laplana Gil, Anejos de Criticón, Presses Universitaires du Mirail, 1998. Alterno por variatio de estilo su nombre real (Céspedes) con los sintagmas «el humanista vallisoletano (o pucelano)» $\mathrm{y}$ «el nieto del Brocense».

7 A. Soria Ortega, El Maestro Fray Manuel de Guerra y Ribera y la oratoria sagrada de su tiempo, estudio preliminar de Francis Cerdan, Granada, Universidad de Granada, 1991.

8 Véase F. Cerdan, «Paravicino y Góngora», Études sur Fray Hortensio Paravicino, pp. 249-259. 
del Seiscientos hasta el desequilibrio que anuncia la decadencia del final de siglo, tan satirizada en el Fray Gerundio del Padre Isla». ${ }^{9}$

Pienso que habría que sumar un quinto: el aplauso y las ampollas que suscitó la Censura de la elocuencia en manteos de las prendas de Ambrosio de Bondía (Triunfo de la verdad, 1649), el propio Céspedes o Ameyugo (Retórica sagrada y evangélica, 1673). Entre dichos novatores, uno de los más olvidados ha sido sin duda fray Martín de Velasco, responsable del Arte de sermones para saber hacerlos y predicarlos (1677). ${ }^{10}$ Miembro de la Orden de San Francisco y Padre de Provincias de Santa Fe de Bogotá en el Nuevo Reino de Granada, se revela heredero de los compendios de Andrés Gerardo, el Maestro Estrada, Terrones, Ameyugo o el Doctor Juan Rodríguez de León. ${ }^{11}$

La obra de este franciscano, «original como pocas en su complicada estructura, procura alumbrar no una Agudeza y arte de ingenio, sino un arte de agudeza, porque, como afirma, a los eruditos en la Retórica "el Arte no les promete ingenio, sino agudeza" ». ${ }^{12}$ Abordo, pues, su pensamiento en función de dos claves: a) sus modelos concionatorios; b) su papel como tardío eslabón en la disputa entre Ormaza y Céspedes.

Con una particularidad: Velasco menciona al autor de la Censura, pero nunca al de Trece por docena, cuya obra seguramente ignorara, pues este último texto solo circuló manuscrito y entre jesuitas. Luego el objetivo de nuestras páginas es deslindar si el libro del colombiano armoniza de algún modo, y en qué puntos, con las tachas que Céspedes, nieto del Brocense, opuso a Pérez de Ledesma. ${ }^{13}$

\section{El Prólogo al Lector}

Fundado en la doctrina de san Agustín, que el mismo santo intitulara Doctrina cristiana, y en la de san Pablo, ${ }^{14}$ el «Prólogo al lector» de Velasco ilumina varios focos de la polémica entre los antiguos y los nuevos predicadores. ${ }^{15}$ La justificación de su Arte

9 F. Cerdan, «Introducción» a Fray Hortensio Paravicino, Sermones cortesanos, Madrid, Castalia, 1994, p. 14.

10 M. de Velasco, Arte de sermones para hacerlos y predicarlos, Cádiz, por el Alférez B. Núñez de Castro, Impresor y Mercader de Libros, c. 1675. La licencia está fechada en 1677, Cádiz, Biblioteca Pública del Estado, XVII / 2803. Modernizo la grafía. Alterno por variatio de estilo el nombre real («Velasco») con los sintagmas «el colombiano», el «bogotano» o «el de Santa Fe».

11 Dado que P. Tanganelli y quien suscribe los estudiamos a todos ellos en una antología de próxima aparición, no me detendré en sus tratados.

12 F. Herrero Salgado, La oratoria sagrada en los siglos XVI y XVII, Madrid, FUE, 1996, p. 242.

${ }_{13}$ Dudo también que Velasco conociera el Triunfo de Bondía, que citaré de forma muy puntual. El lector podrá acceder a un resumen de su pensamiento en Trece por docena, especialmente en los «Azotes X-XII».

14 M. de Velasco, op. cit., fol. 1.

15 Sobre esta antinomia, véase G. Ledda, «Antiguos y nuevos predicadores: una polemica sull'oratoria 
nos llega plagada de retruécanos, en la estela de Ormaza, que no ocultan un exceso de confianza cercano a la vanidad:

Lector, $[\ldots]$ eres austero, quitas lo que no pones y ciegas lo que no sembraste; pero sé también que al cabo del año [...] has de quedar debiéndome a mí lo que a todos; porque de todos murmuras y no hay crédito tan seguro que no quites. Pues acuérdate también de mí cuando restituyas, y si no quieres deberme, olvídate de mí cuando me leas.

Así que me viste con cincuenta y seis años de edad, y con el Arte en las manos, ibas a decir, armado de refranes ofensivos, «ya es viejo Pedro»; pero diera el golpe en otra parte, porque distintas cosas son estudiar en el Arte para saber y saber hacer Arte para que otros estudien. [...]

Dirás que en esta materia hay muchos Artes, y que el mío se vuelva, pues viene tarde. A que respondo que muchos de ellos he leído, pero todos me dan licencia para que el mío se imprima. ${ }^{16}$

El hecho de que aluda a su edad y a su condición de «viejo» evidencia que la sombra de Ormaza -acaso también de sus seguidores- incide sobre esta retórica. Porque el autor de la Censura, conviene adelantarlo, no castigó a los antiguos tan gratuitamente como se ha dicho. En el capítulo I recordaba con nostalgia aquella «feliz edad en que los años no jubilaban al anciano». ${ }^{17}$ Lo que de verdad afea Pérez de Ledesma es la creciente falta de cultura -las «canas ignorantes» a las que se da el grado de maestras-, buen motivo para sancionar una nueva práctica sermonaria sin lugares ni citas que traben el discurso. Una creación «radicalmente literaria, en su tránsito del binomio enargeia / movere a la pareja ekphrasis / delectare»,18 libre de esas autoridades a las que tan inclinados fueron sus mayores.

Ormaza, una suerte de Góngora de los púlpitos, firmó así la segunda de las dos revoluciones -la narrativa y la concionatoria- que no había encarado el genio cordobés, poco dado a observar los ritos y costumbres del clero. Al menos los litúrgicos. Sin embargo, ambos coinciden en un desafío sustantivo: hasta cierto punto, y bastaría con leer las Soledades, Góngora inventó un nuevo género donde la utilidad se sometía al arte descriptivo, como hizo Pérez de Ledesma con sus pinturas imaginarias. Uno y otro idealizan la sustancia poética y sacra, respectivamente, y renuevan su antigua

sacra del '600», Symbolae Pisanae. Studi in onore di Guido Mancini, ed. de B. Periñán e G. Guazzelli, Pisa, Giardini Editori, 1989, pp. 311-325.

16 M. de Velasco, op. cit., fol. 9.

17 G. Pérez de Ledesma, op. cit., p. 49.

18 Véase P. Tanganelli, «La crisis de la oratoria sagrada entre los siglos XVII y XVIII: el Epítome de la elocuencia española de Artiga y los modelos descriptivos de la predicación gerundiana», Annali Online di Ferrara-Lettere, 1 (2008), pp. 124-138 (p. 125). Más allá de la rentabilidad pedagógica («para atar el conocimiento»), se ha insistido poco en la defensa que Céspedes hace de los lugares no como fuentes de la Escritura, sino como minas para la agudeza; esto es, más por su peso retórico que escolástico: «¿quién podrá dudar que en las historias de los Patriarcas se pueden levantar agudezas muy morales, muy delgadas y muy proprias?». Véase V. de Céspedes, op. cit., p. 83. 
función, derribando incluso la noción del «poeta profeta» y del «rétor como vehículo doctrinal» para transformarlas en las del vate y predicador artífices, conocedores de los latinos y del Evangelio, pero hechos a sí mismos a fuerza de ingenio y erudición. ${ }^{19}$

Por adoptar la clasificación de Díaz Lavado, el aragonés es el primero en prescindir de la retórica como «texto citante» $\mathrm{y}$, en consecuencia, relega a segundo plano los textos citados, embutidos en el propio discurso, ${ }^{20}$ ya que, a su parecer, ni sirven al ornato ni poseen más brillo que el de su ingenio.

Miembro de la generación anterior, Céspedes refutaba justo aquello de lo que se ufana el Censor: su altanería con los antiguos y su penuria de fuentes. Opina Mercedes Blanco que para el humanista vallisoletano «no hay vanidad erudita en la cita, sino honesta labor filológica, amor a la verdad depositada en el tesoro de las letras, modesta prudencia de quien reconoce la superioridad del pensamiento de los santos, y cristiana humildad de quien se inclina ante el texto inspirado». ${ }^{21}$

Habida cuenta de esta batalla, resulta curioso que Velasco caiga a veces en la misma soberbia («si no quieres deberme, olvídate de mí cuando me leas») que se afanaba en desterrar de los altares. Bastante parecida, por cierto, a la de Ormaza en su capítulo II: «sobre las causas que tienen tartamuda a nuestra elocuencia, siento casi forzoso comenzar incurriendo en una de ellas. Ha podido tanto con nuestra ignorancia la vanidad de eruditos, que estimamos más parecer leídos que ingeniosos». ${ }^{22}$ En líneas generales, el colombiano tiende a alistarse del lado de los conservadores, o sea, junto a Céspedes, pero toma más de una idea del aragonés. Y es que los corrillos que opusieron

19 Sobre Góngora como poeta artifex, véase A. Collard, Nueva poesía. Conceptismo, culteranismo en la crítica española, Madrid, Castalia, 1971, p. 102. Matizo, no obstante, que Céspedes, como Ormaza y Velasco, no niega la calidad del ingenio para la formación de conceptos: «el estilo es negocio que se aprende o con la disciplina o con el uso; los conceptos no se aprenden, ni tienen otra oficina sino el ingenio». Véase V. de Céspedes, op. cit., p. 169.

20 Véase F. Herrero Salgado, «Las citas en los sermones del Siglo de Oro», Criticón, 84/85, pp. 63-79 (p. 64). Hago notar que la preeminencia y asunción del delectare habían sido adelantadas por G. Salcedo de Aguirre en «XII. Letra para un sacerdote que quiere començar a Predicar: en que aviéndose tratado de los tres officios principales del Predicador, se le dan algunos avisos: finalmente se trata de las partes del sermón: y de la pronunciación o acciones del Predicador», incluida en su Pliego de Cartas en que ay doze epístolas escritas a personas de diferentes estados y officios..., Baeça, por I. Baptista de Montoya, 1594, fols. 172v-204r. Remito también al epígrafe "Una digresión: la descriptio en las retóricas eclesiásticas del XVI" del artículo de P. Tanganelli, «En torno a las interpolaciones del Cántico B: algunas peculiaridades léxicas y una nueva técnica descriptiva», San Juan de la Cruz, XXIV, 42, pp. 57-106.

${ }_{21} \mathrm{M}$. Blanco, «Humanismo rezagado frente a difícil modernidad. Al margen de la polémica OrmazaCéspedes sobre la oratoria sagrada», Criticón, 84-85 (2002), pp. 123-144 (p. 141). A. de Bondía, Triunfo de la verdad sobre la Censura de la elocuencia, Madrid, J. Martín de Barrio, 1649, Biblioteca Histórica-F. Antiguo, Universidad Complutense de Madrid, BH FLL 26005, había denunciado que «parece que se declara por maestro de muchachos, pues amenaza con la docena: [...] solo puede tener disculpa en el juicio o en la ignorancia del peligro; pero al fin ignorancia, y no de maestro de muchachos sino de muchacho entre maestros» (fol. 5). Modernizo la grafía.

22 G. Pérez de Ledesma, op. cit., p. 55. 
a los antiguos frente a los jóvenes, con Pérez de Ledesma a la cabeza, no son del todo exactos y hoy suenan hasta maniqueos.

Según Cerdan y Laplana, el Censor, mostrando cierta indulgencia con los que batían sus primeras armas, no vaciló en arremeter contra la casi totalidad de los predicadores de su tiempo: «El modo en que hoy se predica es el mayor contrario de la Elocuencia» reza el capítulo V. Y condena en el III tanto a «los "desaliñados", que suele identificar con los más ancianos, [...] como a los más modernos, "los picados de agudos [que] todo lo quieren llevar a punta de concepto, como de lanza" $»{ }^{23}$ Sin embargo, Velasco no ataca a Ormaza con tanta fiereza como Céspedes o Bondía, que propuso una contrarretórica en la que da licitud a la «predicación alta de entonces, en detrimento de la llamada «predicación común o baja (rústica o rural), y devuelve a Paravicino su primacía como máximo exponente del género». ${ }^{24}$ Es más, el Arte de sermones de Velasco tiende a ser bastante tibio en sus loas al autor de las Oraciones evangélicas. Casi no alude a él, y lo hace solo al final, cuando celebra la habilidad de fray Hortensio para representar las cosas con «fantasías» mejor que con palabras (cap. XXVII). ${ }^{25}$

Aunque Velasco escribe «con claridad y llaneza, procurando que el estilo no sea muy elegante, sino competente, porque la elegancia muchas veces escurece las cosas y la propiedad las declara», ${ }^{26}$ dos detalles repercuten sobre lo que sabemos de los dos jesuitas en liza. A mitad de camino entre lo plasmado en la Censura y en Trece por docena: 1) Velasco admite un género de sermón «con partes en las que parece que declina de lo grave tal vez a la fatiga, y otras a la chanza»;27 2) valedor de los lugares historiales, como Céspedes, apuesta en cambio por dosificarlos. Apenas taracea su prosa con citas de los Padres de la Iglesia. Acude con cuentagotas tanto a san Agustín como a san Pablo y, al igual que José de Ormaza, reniega de las planas de erudición y de las autoridades: «no cito autores por dos razones: porque hablo con razón; y en donde esta sobra, la erudición no hace falta, y para Arte no es menester más que razón». ${ }^{28}$

23 F. Cerdan y J. E. Laplana, «Introducción» a V. de Céspedes, Trece por docena, p. 23.

${ }^{24}$ J. Ramos Domingo, Retórica - Sermón - Imagen, Salamanca, Universidad Pontificia de Salamanca / Caja Duero, 1997, p. 157. Quizá la pequeña «obra maestra» del Triunfo de Bondía sea el vejamen contra Ormaza que cierra su libro, una vez se ha despachado contra él acusándolo de usurpar el título de Maestro que no poseía. Véase J. E. Laplana Gil, «Un vejamen en un tratado de predicación: el Triunfo de la Verdad (Madrid, 1649) de Ambrosio de Bondía», Archivo de Filología Aragonesa, XLIV-XLV, Instituto Fernando el Católico, Fundación Pública de la Diputación de Zaragoza, 1990, pp. 179-208.

25 M. de Velasco, op. cit., fol. 218.

26 Ibidem, fol. 10.

27 Ibidem, fol. 10.

28 Ibidem, fol. 10. Según M. Beuchot, «La retórica argumentativa de Fray Martín de Velasco (Colombia, 
Dicho de otro modo: Velasco copió al Censor cuando este declaraba la impronta sobre él del libro IV de la Doctrina cristiana:

Sobrará para el desempeño San Agustín, en lo divino y humano oráculo de la Iglesia, ostentación de la Sabiduría Eterna y vanidad cuerda de la Naturaleza. En sus obras he hallado esparcidas las mejores advertencias del orador eclesiástico; pero, quien las quiere ver juntas, lea los libros de Doctrina Christiana, en especial los tres últimos capítulos del segundo libro, donde dice que se lean los Étnicos y Profanos autores. ${ }^{29}$

Si bien Velasco se acoge al magisterio del predicador de Hipona solo para «reducir las partes del sermón a sus lugares propios y nativos». ${ }^{30}$ Incluidos los que -sin publicarlo del todo- había aprovechado ya el «bando elocuente» de Ormaza. Este retrato de las dos facciones oratorias del XVII coincide en gran medida con lo que se dice en las páginas de Céspedes. Pero el nieto del Brocense defendía el uso de lugares y autoridades, que asoman por cada uno de los «azotes» en los que divide Trece por docena; ya sean latinas o españolas, sacras o profanas. Por no hablar de su gavilla de cuentos orales y escritos. Velasco huye en cambio de la cita escolástica, elide la técnica de marquetería para estructurar su retórica y, a pesar de todo, cuando lo juzgábamos ya entre los fieles del Censor, arroja varias pullas sobre Pérez de Ledesma. Curiosamente, se nos presenta como un clérigo teñido de ormazianismo. Con más asiduidad de la que sospecha o deja entrever.

Comenzaré, no obstante, por uno de sus chuzos contra el aragonés:

todos se precian de elocuentes y pocos sirven a la elocuencia. Muchos aficionados y ninguno que la defienda, ni que riña sus pendencias. [...] De estos fue el "Censurador de la elocuencia» -dígolo claro, porque él aún no ha sacado la cara-, que, siendo ingenioso, se hizo ingeniero en daño conocido del Método y Arte. Inventó trabucos para volar proposiciones. Y otras cosas semejantes con que asoló las provincias de los discursos con notable descalabro de los conceptos. ${ }^{31}$

Es la respuesta de Velasco a una de las ideas más penetrantes de Ormaza: la alianza entre devoción e ingenio: «Ni las voces desacrediten el discurso, ni este haga burlas de ellas. Únanse sus plumas como en cañones de batir, donde el estruendo sirve para el pavor, la bala para la herida y de ambos es la victoria». ${ }^{32}$ Así, Tanganelli

siglo XVIII)», Endoxa, 6 (1995), pp. 167-179, «su obra ha querido ser una apuesta a favor de la razón, pero de una razón que impregna diversamente (en distintas medidas, pero sin llegar a diluirse ni a trivializarse las cosas que ilumina». Estoy de acuerdo con M. Blanco, op. cit., p. 138, cuando sentencia que «aunque Ormaza echa mano de esta doctrina clásica, tomada del De doctrina christiana de San Agustín, en el fondo no sabe qué hacerse con ella; la expone tan confusamente que a Céspedes le cuesta poco esfuerzo poner en evidencia y en solfa tanta inconsistencia».

29 G. Pérez de Ledesma, op. cit., p. 56.

30 M. de Velasco, op. cit., fol. 11.

31 Ibidem, fols. 12 y 14.

32 G. Pérez de Ledesma, op. cit., p. 64. 
ha observado que «la Censura sembra anticipare [...] quella seconda fase della retorica gesuitica più indulgente verso le squisitezze alessandrine, oramai in sintonia con le invenzioni ingegnose ed epigrammatiche di un Gracián o di un Tesauro, che abbandona come compendio retorico di riferimento l'antiquato manuale di Cipriano Suárez». ${ }^{33}$

Aunque el prólogo del franciscano se haga eco de los aprietos para fijar el significado de «ingenio», «agudeza» y «concepto», sobre los que volveremos, uno de los pilares de esta controversia, la última cita («porque él aún no ha sacado la cara») y su voluntad de hermanarse con san Pablo, conciernen de nuevo a la querelle de los antiguos frente a los modernos. Aclaro que tanto Ormaza, cuando asumió el disfraz de Pérez de Ledesma, como Céspedes, parapetado tras el de Juan de la Encina en su libro, cuyo jocoso timbre remite a Quevedo y al inventor de la literatura del disparate (Trece por docena. Censura Censurae por Musa Musae para enseñar a un pároulo a que decline de muchos desatinos pueriles con que le tentó el Diablo a hacerse por ensalmo predicador dogmatizante de la nueva garapiña), ocultaron sus nombres reales.

Por encima de este baile de máscaras, Céspedes enseguida se jacta de no haber pecado en nada: «porque hablo solamente con él». Y a fe que no miente, pues se apresura a herir al intrépido Pérez de Ledesma con hoja de tinta fina. Recordemos que Trece por docena se organiza en «azotes» y que, a juicio del nieto del Brocense, el atrevimiento del «hereje» Ormaza, fruto de la «flaqueza de su seso» y de la «osadía de su mocedad», no merecía golpes en la cabeza sino en el trasero.

Ahora se entiende mejor la cita del proemio de Velasco: el colombiano evocaba a san Pablo porque también el apóstol había usado «un grande artificio en el "Prólogo" de sus Epístolas». ${ }^{34}$ Más aún: solo si tenemos noticia de esta premisa -los disfraces de uno y otro sacerdote-, descodificaremos la ironía de Velasco cuando menciona al predicador de Tarso: si Ormaza se negó a censurar a los antiguos a cara descubierta, san Pablo también había ocultado su nombre en el «Prólogo a los Hebreos». Luego, al igual que Céspedes, metamorfoseado en Juan de la Encina e inventor de «Boceguillas» como sede de impresión para su libro, Velasco dirige un guiño cómplice a sus lectores: cita a un orador enmascarado, por muy apóstol que fuera, para criticar a otro. ${ }^{35}$

\footnotetext{
33 P. Tanganelli, La descrizione nella Spagna del XVII secolo. Retorica e Predicazione, Graphis, 2004, p. 58.

${ }_{34}$ M. de Velasco, op. cit., fol. 16.

35 Respecto a su impostura, A. de Bondía, op. cit., fol. 11, subrayó que «no soy de parecer que sea Doctor ni Maestro, $[\ldots]$ y aunque conozco que se hizo máscara para tomarse libertad y desahogo, las licencias del decir y, con la misma libertad, oír -pues para eso se hacen las máscaras los presumidos-; y así, que merecía llamarse el "Licenciado Máscara", porque a todos mascara, que ya sabrá el tropo que es gran retórico de tropelías».
} 
Y otro detalle. El de Santa Fe asegura que si escribiera para los «comuneros», o sea, los revolucionarios que desmembraron Castilla, se alzaron contra la corona y «entablaron el aborrecimiento de las Indias», no hubiese dudado en valerse de otro alias, pues aquellos se resistían a la presencia de intelectuales en Nueva España. Si extrapolamos esta pequeña anécdota, la propia revuelta y su condición de colombiano al mundo de la oratoria, es fácil deducir que Velasco asocia a los comuneros con los «amotinados» que siguieron a Ormaza; es decir, con todos los que se levantaron contra la «monarquía antigua». De ahí que los fines que mueven a nuestro hombre no sean muy distintos de los de Céspedes cuando embestía contra Pérez de Ledesma. Hasta el punto de que, aun coqueteando con los descaros del Censor, Velasco se dirige a los viejos predicadores y firma con su nombre de pila: «Pero siendo pregmática [sic] tan justa que el libro salga con el nombre y patria de su dueño, hágalo como se manda, logrando en esta obediencia un artificio para mí de mucho provecho. $\mathrm{Y}$ en este pongo en la inscripción el nombre, para abrir en muchos el deseo de la doctrina y para cerrar con él la puerta a los comuneros». ${ }^{36}$

\section{Partes esenciales y Materiales}

Los capítulos de cuño agustiniano y quintilianista sobre las partes esenciales del sermón, «enseñar», «deleitar» $\mathrm{y}$ «mover», no suponen una aportación significativa. Tampoco las fases para desarrollarlas oportunamente: «Inventar qué y cómo; de lo inventado elegir lo mejor y más a propósito; y de lo elegido disponer en sus lugares. Y lo así dispuesto, escribirlo, decirlo y predicarlo. Y estas cuatro cosas se llaman las "partes integrales" de la Rectórica: invención, elección, disposición y pronunciación». ${ }^{37}$ Mucho más original y cercana a la trifulca entre Ormaza y Céspedes es la dificultad para levantar una buena pieza oratoria, consecuencia de los apuros que entraña «dar con el artificio». Velasco resucita así el criterio de uno de sus maestros, diana a la sazón para varias invectivas del Censor tres décadas antes. Según el franciscano, «algunos dieron preceptos para pulir las partes, como Gracián en su Arte de ingenio; otros notaron los yerros, como el "Censurador de la elocuencia"; y muchos salieron confusos. Todo es menester saber: evitar los yerros, disponer las partes y perficionar el todo». ${ }^{38}$

El fraile bogotano sugiere un proceso más gradual: Gracián es uno de sus teóricos de cabecera y Ormaza («otros notaron los yerros») el corrector de lo sancionado por

\footnotetext{
36 M. de Velasco, op. cit., fol. 16-17.

37 Ibidem, fols. 21-22.

38 Ibidem, fols. 20. P. Tanganelli, La descrizione, p. 75, apunta que «si direbbe, però, che Velasco apprezzi solo la pars destruens della teoria concettistica ormaziana, che retiene comunque nel complexo extremamente pericolosa».
} 
aquel. Velasco, en cambio, los considera compatibles para asentar su Arte. Sin embargo, hay que tener en cuenta que Pérez de Ledesma se atrevió a prescindir del autor del Criticón, discutiéndole su primacía en lo que atañe a los conceptos y arrogándose ese liderazgo: «Siendo la agudeza en los conceptos único parto de la valentía del ingenio, vanamente ha intentado un Escritor moderno hacer Arte de Agudeza (mejor le llamara cuento de cuentos) para aguzar ingenios y delgaçar conceptos botos, como si esto fuera oficio de afilar cuchillos».39

Intentaré aclarar la oposición entre ambos. El incisivo Ormaza ataca a Gracián cuando discurre sobre el «estilo breve con agudeza», ya que la Censura relaciona el ingenio con algo bastante próximo al furor poético, en la línea neoplatónica. Desconfía, pues, de quienes aprenden a ser agudos -y por ello a formar conceptos- solo en las retóricas, que a él le resultan estériles si no están sometidas al talento natural. ${ }^{40}$

Por el contrario, Velasco sí cree en dicho aprendizaje y lo subraya a propósito no de la elocutio, donde suele coincidir con Ormaza, sino de la dispositio del sermón. Recupero ahora unas palabras de Bondía a favor de Gracián: «pregúntole yo ahora ¿por qué le dice aquellas sátiras tan perjudiciales al escritor moderno que ha sacado a luz el arte de ingenio? Que cosa tan salada es el apodo que le echa, diciéndole "cuento de cuentos"».41

Luego esta situación conduce a dos claves por explicar: 1) el Arte de sermones no se propone reproducir el esquema de la retórica puramente formal, es decir, la de los tropos y las figuras. Como Baltasar Gracián en su Agudeza, el colombiano redacta una retórica ideológica donde el estilo se subordina siempre a los pensamientos y, más aún, a la ordenación de los mismos; 2) en virtud de la soberanía que otorga a la segunda parte de la retórica quintilianista (dispositio) sobre la tercera (elocutio), Velasco nos entrega un Arte fundamentalmente dialéctico: es decir, un "Arte de agudeza», porque la defensa del ingenio era uno de los ejes sobre los que giraba la Ratio studiorum. ${ }^{42}$

Tripartita y también gastada resulta su clasificación de las partes materiales (capítulo II): 1) introducción; 2) orden de discursos; 3) dentro de estos, el orden y el lugar de los conceptos. Todo debe estar regido por la lógica -que impide el trueque de «posiciones»y «lugares»- y por la trabazón de los «conceptos». Buen momento, pues, para deslizar que «no has de imitar a muchos libros de sermones que andan con sus

39 G. Pérez de Ledesma, op. cit., pp. 115-116.

40 Ibidem, p. 150.

41 A. de Bondía, op. cit., fol. 99.

${ }^{42}$ Remito a J. M. Ayala, «Un arte para el ingenio», «Introducción» a B. Gracián, Agudeza y Arte de Ingenio, ed. C. Peralta, J. M. Ayala y J. Ma . Andreu, Zaragoza, Larumbe, 2004, I, pp. XIII-CXIII (pp. XLI-XLIV). 
conceptos muy numerados al margen, no teniendo más razón para primeros que el antojo». ${ }^{43}$ Velasco define el texto como un artefacto retórico en el que cada parte nace invariable, diseñada con anterioridad. En función de tales normas, la propia dispositio liberaría al predicador de glosar sus propias agudezas. Cuando el sermón está bien construido, se sucederán y percibirán de manera natural. Es el único modo para que no derive en un galimatías o «precipicio oratorio».

Reparo en este apunte porque coincide con los de Ormaza en el capítulo «Nivel para reconocer los defectos o aciertos del sermón»: «También se note si el segundo lugar adelanta claramente el empeño del primero, dando novedad al discurso; y si uno solo se lleva toda la hora, será molesto y de poca enseñanza; si lleva muchos desunidos, será libro desencuadernado. La destreza es eslabonarlos de modo que unos llamen a otros con unión y variedad». ${ }^{44}$ Pero la toma de partido del bogotano a favor de Pérez de Ledesma no impide que le enderece un azote sobre la aplicación práctica de sus teorías en el Sermón en la Asunción de María Señora, que cierra la Censura de la elocuencia. De hecho, el mismo Ormaza, que apuesta por eslabonar los conceptos, omitiendo así los marginalia, también dejó al descubierto las muletas concionatorias (las fuentes en los ladillos del folio) en el citado Sermón, para que los rétores aprendan «la arquitectura que hemos ideado hasta aquí». ${ }^{45}$

En su afán por distribuir su Arte en tríadas, Velasco indica que el discurso debe atesorar algunas cualidades para que todos los «números» sean apropiados: ha de ser «fundado» (enseñar), «lucido» (deleitar) y «provechoso» (conmover). Para la primera se necesita, por este orden, la narración, división, confirmación y refutación del asunto, siempre que el tema lo pida. Para exornarlo («lucido»), la oratoria cuenta en cambio con amplísimos almacenes de figuras y tropos en los que apoyarse. Finalmente, la utilidad, secuela de las dos anteriores, invita a pensar que para escribir el sermón perfecto hay que respetar tres «formas parciales» durante el artificio: 1) forma fundamental; 2) forma de exornación; y 3) forma de provecho. Con tales principios, la «introducción» definirá, advertirá y hasta declarará a los fieles la materia objeto de prédica, colocando un «lugar fundamental» junto a los del Evangelio. El pórtico para una distribución del contenido del sermón en tres partes, que se corresponden con los tres discursos, perfectamente encadenados. Esta definición de la materia es lo que los clásicos llamaban «hipótesis», «argumento», «suposición» o «propuesta».

\footnotetext{
43 M. de Velasco, op. cit., fol. 23.

44 G. Pérez de Ledesma, op. cit., p. 169.

45 Ibidem, pp. 183-206. V. de Céspedes, op. cit., p. 77, se detuvo en la misma inconsecuencia que nota Velasco: «No se puede con eso negar que el sermón es lo menos malo del libro, porque al fin rompió en él cuantos preceptos había puesto».
} 
Pues bien, el predicador novohispano se muestra tan sugestivo como poco ormaziano cuando sanciona la división de la materia, del tema y del lugar fundamental en tres bloques dentro de la misma introducción. Y menos todavía cuando hace bandera de una agudeza («siempre has de procurar mostrarse ingenioso de briosa inventiva») ${ }^{46}$ que huya de «lo paradójico» y de «lo fantástico» en los asuntos. Para el franciscano, la agudeza, al menos en estas primeras etapas, no obedece al estilo, sino a la organización de los argumentos. Y no duda en listar todo un elenco de modelos, en la órbita de lo aducido por Céspedes: «aprenderás a hacer con agudeza la división si te vales de los predicadores antiguos latinos; S. Antonio de Padua, S. Antonino, S. Bernardino, etc. Y podrás ver y imitar muchas en el Cardenal Hugo, en la explicación de los Salmos y en los Sermones de Armando de Bello». ${ }^{47}$

Sentada la división general, comenzará el primer discurso. Una tarea que exige que las palabras sean claras, pues «si faltan aquí las luces (como las lámparas de las otras), se cerrará la puerta y quedará todo el sermón a escuras». ${ }^{48}$ También aquí parece rebatir a Ormaza, valedor de un estilo conceptuoso que no rebase ciertos límites, pero enemigo de todo aquel que prescinda de los colores retóricos y de las picanterías. ${ }^{49}$ Pero Velasco mantiene una actitud cauta respecto a los reproches que vertieron sobre el aragonés tanto Bondía como Céspedes. Quiero decir que durante su exposición se escuda en un lugar -a lo sumo dos- de las Sagradas Escrituras, menguando el uso de autoridades frente a las del pucelano. Si bien critica a los que se sujetan a un concepto -sin aclarar el sentido del término- para construir discursos que carecen de brújula y de camino. A fin de cuentas, igual que Ormaza cuando desgranaba en la segunda parte de la Censura su serie de pinturas sobre el «falso ambicioso», el «murmurador maligno y chismoso», el «pobre pretendiente» o la «triunfante Ascensión». Según el colombiano, los conceptos deben ser como los «jinetes en la guerra». Correctamente ordenados lograrán la victoria, animándose entre todos y cada uno de por sí. Su misión no es sino exhibir cuatro virtudes: 1) la fuerza del argumento; 2) la destreza en vencer la dificultad; 3) el «a propósito» del intento; 4) el arte con que se ha jugado todo.

Desnudez teórica -casi minimalista- que vuelve a cebarse con varias reflexiones del aragonés:

Dirán los de aquesta secta que ellos (porque no esté tan solo el concepto) lo acompañan de variedad, con adornada elocuencia de «cambiantes plumajes y tornasoles». Esto es lo peor que cometen estos pintores, desacreditando a la

\footnotetext{
46 M. de Velasco, op. cit., fol. 28.

47 Ibidem, fol. 29.

48 Ibidem, fol. 30.

49 G. Pérez de Ledesma, op. cit., p. 65.
} 
elocuencia, pues intentan que sus primores sirvan al desorden al desaliño y a la soledad: como si la mona, adornada de galas, no fuera mona y más fea. ${ }^{50}$

Vaya por delante que Ormaza es acérrimo guardián del orden conceptual. Sin embargo, para librarse paulatinamente de los lugares, respalda una retórica en la que el «estilo no es solo la parte principal sino el todo del Orador». ${ }^{51}$ De otro modo: igual que Céspedes y Velasco, Pérez de Ledesma evita la afectación; incluso cuando habla de «acicalar la sentencia con palabras picantes, vivas, propias, mas no ruidosas, que no pretendo quebrar cabezas, sino herir corazones».52 Pienso que tanto en esta casuística como en lo relativo a Paravicino coinciden los tres sacerdotes. Recordemos que Ormaza había alabado el ingenio del gran predicador, aun matizando que tendía a excederse y no le parecía el mejor modelo para los jóvenes. Céspedes, por su parte, tampoco perdió ocasión de elogiarlo, mientras glosa que los antídotos para sus bizarrías conceptistas atienden por Ávila, Granada y Tomás de Jesús. ${ }^{53}$

A renglón seguido, Velasco escribe que una «transición» ha de ser el pasadizo que nos lleve del primer al segundo discurso. Concreta dos tipos: 1) las nacidas de la naturaleza de las cosas, que son las mejores; y 2) las que se construyen a partir de la artificiosa composición de las palabras. Lógicamente, los prudentes optimizarán las sentencias, disponiéndolas de modo que dejen algún cabo suelto para enlazarle el siguiente concepto.

El segundo artificio en las partes materiales es colocar en ellas «el orden de la Retórica». Siempre por lo que atañe a sus partes integrales. Un proceso que implica desmenuzar algo más la caja china de reglas descritas al inicio. Si antes acentuábamos la rígida estructura de la introducción, Velasco se recrea ahora en las piezas que facilitan el engranaje de los discursos, conceptos y transiciones: 1) introducción menor para cada uno de los discursos; 2) introducción menor para cada uno de los conceptos en los que estos se articulan; 3) el discurso finaliza justo donde acabe su último concepto; 4) transiciones nítidas y bien fundadas de discurso a discurso y de concepto a concepto.

50 M. de Velasco, op. cit., fol. 33.

${ }^{51}$ G. Pérez de Ledesma, op. cit., p. 82.

${ }^{52}$ Ibidem, p. 86.

53 A pesar de todo, el ambiguo Ormaza copia sus palabras más de una vez. Así, según F. Cerdan, «Estudio preliminar» a A. Soria Ortega, El maestro Fray Manuel de Guerra, p. XVII, es un «imitador abierto y confeso en ciertos casos, pero también disimulado plagiario en otros. En el capítulo XXVII de la Censura de la elocuencia, donde habla «De los lugares que se componen de Descripción», insiste en las descripciones «que tiene más inventiva y las podemos llamar imaginarias, en que se pintan no cómo fueron las cosas, sino cómo más a nuestro modo las podemos delinear». El Padre Ormaza explica que esas pinturas sirven para mover afectos en el auditorio de manera muy oportuna, y propone un ejemplo preciso para la fiesta de la Anunciación, confesando: «en parte me valí de Hortensio, cuando describe la embaxada de la Encarnación». 
Vemos, pues, que su capítulo sobre las partes materiales no añade datos de valor. Velasco, como otros epígonos de Cicerón y Quintiliano, afirma que la «invención» sirve para especular y discurrir, «buscando por lo que ya sabes» -se colige que las Escrituras y sus exégetas- la idea central. A la invención se suma la «elección»; la «disposición», que pide erudición y brevedad, de manera que las introducciones sean menores que los discursos, conceptos, transiciones y finales; y la «pronunciación» de modos «naturales, propios, llanos, significativos, sentenciosos y perficionados con el Arte».54

Acerca de la segunda forma de artificio («exornación») y de sus lazos con las diversas partes, sostiene que la invención tiene su puesto en las introducciones mayores y menores y debe realizarse con arte, propiedad y facilidad, evitando hablar de uno mismo. Aunque hay atrevidos que soslayan la primera parte, Velasco recomienda su uso por dos motivos: 1) los oradores clásicos gestaron este tipo de exordio para medir la atención de los oyentes; 2) no disponían de tantos modelos como para alejarse de ellos. Fundadores de esta disciplina, se atenían a los pasos para entrar en los asuntos, y este rigor, que implica un dardo contra Ormaza, es el que tendrían que adoptar los jóvenes del Seiscientos. Porque solo cuando alguno «sea San Bernardo o tenga la autoridad de San Ambrosio» podrá salirse un punto de lo establecido.

\section{TeORía de LOS ESTILOS}

Una vez desbrozados los criterios de elección y disposición, Velasco aborda el capítulo más sugestivo de su libro: la pronunciación o elocuencia. Entiende que esta siempre se acomodará a los estilos, pues deriva de ellos y no al contrario. De ahí que el rudimento exigible a todo predicador sea el aprendizaje de los "géneros de estilo», de menor a mayor ornato: 1) remiso o sumiso; 2) blando o templado; 3) magnílocuo o grandílocuo. El remiso es el «natural pulido, discursivo y lleno sentencias»; el blando es el «natural significativo, claro y elegante». Por último, el magnílocuo es el «natural grande, grave, sentencioso, ponderativo y persuasivo». ${ }^{55}$

Dicha jerarquía lleva a pensar que cada uno de ellos remacha, o mejor, define, las partes esenciales del sermón: enseñar, deleitar y mover. Así, para alcanzar esta última, hace falta un despliegue que no poseen los dos primeros. Velasco, perfilándolas ligeramente, copia aquí varias ideas de Ormaza. El jesuita había consagrado seis capítulos de la Censura a los tipos de elocuencia. Piedras de toque para analizar los que plantea el bogotano. Así, Pérez de Ledesma en el XI estableció cuatro «estilos

\footnotetext{
54 M. de Velasco, op. cit., fol. 38.

55 M. de Velasco, op. cit., fol. 46.
} 
enquistados» que avienen, aunque no del todo, con la división de Velasco, que confunde lo que el aragonés llamó «géneros del buen estilo» con «tipos o géneros de estilo». Porque en el texto de Ormaza la voz «género» alude también a la modalidad literaria en la que se aplican los estilos. Más aún: Ormaza distingue estilos defectuosos, por así llamarlos, cuando se ejercitan en géneros que no tienen por qué serlo.

Una apostilla: Velasco solo diferencia los géneros dentro de un estilo neutro. Ni bueno, ni malo. No entra en detalles. Ormaza sí reprobaba el estilo «hinchado», que grosso modo se opone al género "grandílocuo» del Arte de sermones; el «humilde», que halla su correlato en el «remiso»; el «pueril», que merecerá glosa aparte, puesto que Velasco lo ignora; y el «afectado lacónico», también ausente de la obra novohispana. Para Ormaza, el hinchado o «cacozelo» es el más peligroso, como también argumenta Velasco. No obstante, el jesuita con más tino que el franciscano, se tomó la molestia de examinar cuáles son las especies de hinchazón, corolario del auge en su tiempo de los poetas y oradores culteranos: 1) la de palabras (neologismos, extranjerismos, sinónimos y perífrasis), sufrida por los andaluces hasta que Córdoba -en clara alusión a Góngora- «se purgó de esta calumnia» para convertirse en «solar del ingenio y patria del mejor lenguaje»; 2) la arrogancia de conceptos (metáforas audaces, excesos léxicos), con frecuencia nacidos de la primera y siempre más tolerables en verso que en prosa; 3) la unión de conceptos y voces altivas, que tienden a hacer el estilo oscuro y afectado. ${ }^{56}$ Como ejemplo de estos extremos, cita al maestro por antonomasia de la tercera etapa de la oratoria peninsular:

Si hubiera puesto el Reverendísimo Padre Maestro Hortensio leyes a las demasías de su ingenio, merecería sin disputa el primer lugar de nuestra Oratoria. Mas tanto se yerra el tiro por alto, como por la bajo. Por altísimo perdió no pocos aciertos este gran ingenio, de quien se duda si adelantó la habla castellana con lo animoso de sus voces, o la deslució con lo licencioso y arrojado de sus metáforas. ${ }^{57}$

Pero la simetría entre Ormaza y el bogotano se vuelve contraste cuando evaluamos el estilo humilde (Pérez de Ledesma) en relación con el sumiso (Velasco). Si el sumiso era fuente de claridad y elegancia para el de Santa Fe, el Censor, que teoriza a favor del «concepto» -entendido al modo de Gracián-, opina que es tan denunciable como el hinchado. Basta leer su crítica de las voces rústicas («gañote», «chirriar»,

\footnotetext{
56 G. Pérez de Ledesma, op. cit., p. 91. La realidad, como observa J. JuRADO, «Fray Gerundio y la oratoria sagrada barroca», Edad de Oro, VIII (1989), pp. 97-105, es que «a partir de 1588 los tratadistas españoles de elocuencia sagrada vienen ya castigando con dureza el estilo retorcido, hinchado y culto por inconveniente e inapropiado para el púlpito. Se evidencia así en diversos lugares de De sacra ratione concionandi (Barcelona, 1588), el extenso tratado de Fray Diego Pérez de Valdivia, en otros tantos correspondientes a los libros III y IV del De sapiente fructuoso (Burgos, 1589), del jesuita salmantino Juan Bonifacio y, por supuesto, en la Instrucción de Predicadores (Granada, 1617) de Francisco Terrones» (p. 100).

57 G. Pérez de Ledesma, op. cit., p. 95.
} 
«chorro») o demasiado caseras («lomos», «carabuezo»), entre las que sitúa los refranes y modillos burlescos. ${ }^{58} \mathrm{~A}$ la espera de que se analicen las artes praedicandi como altavoz de lo prescrito por los gramáticos del Barroco, algunos de los cuales pertenecían al clero, me limito a señalar que Ormaza se afilia al clasicismo de Nebrija, castigando la naturalidad que Juan de Valdés había sancionado en su Diálogo de la lengua. Tratado que puso de manifiesto la importancia del uso para el aprendizaje del romance, más identificado con los refranes que con las autoridades latinizantes (la época imperial, Mena, Santillana...).

No obstante, Pérez de Ledesma se permite un capricho: los modillos son utilizables en las sátiras: «como se ve en Horacio, Persio, Juvenal, y otros, y en los que puede oponerles con Vitoria nuestra lengua Don Luis de Góngora y Don Francisco de Quevedo, que no solo en el verso mas en la prosa satírica usan estos modos caseros».59 Otra clave de su finura como exégeta. Si el Censor, de forma muy moderna, supo explicar los estilos de acuerdo con su aplicación en los géneros literarios, y eso que alguno todavía andaba en mantillas, el franciscano no se detiene en matices y endereza su teoría sobre una lengua -o sobre un registro- que solo cabría juzgar estandarizada para el púlpito. Bien poca cosa.

Por último, según Ormaza, el tercer defecto del estilo humilde es abusar de las palabras sin brío y de la epítesis. De ahí que el «pueril», diferido por Velasco a capítulos posteriores, se corresponda con el que «niñea en ponderaciones, digresiones inútiles, ostentación intempestiva de noticias [...] y finalmente en equívocos». ${ }^{60} \mathrm{Sin}$ olvidar las metáforas demasiado alegóricas. Para el aragonés los más pueriles son los equívocos que constan de retruécano y sonsonete de palabras. Y al contrario. Suenan muy airosos los que surgen de la alusión a las cosas. Dicho de otro modo: su lectura de este asunto es muy gracianesca, en tanto que aboga por conceptos que expriman la correspondencia entre unas cosas y otras. Un conceptismo nacido del intelecto, de las connotaciones de la res, y no tanto de las paronomasias, calambures, retruécanos, etc.

El jesuita termina por flagelar a los que porfían en el «afectado lacónico»; pues, preciándose de sentenciosos, lo único que hacen es cerrar las cláusulas de repente: «ya les parece que son unos Sénecas. También estos imitan solo lo tartamudo». ${ }^{61} \mathrm{Y}$ refiere que quienes ejercitan una taracea de estilos no cocinan sino una «ensalada de todas las yerbas». ${ }^{62}$ Se hace perentorio, en definitiva, un andamiaje teórico que explique lo que

\footnotetext{
58 Ibidem, p. 97.

59 G. Pérez de Ledesma, pp. 97-98.

${ }^{60}$ Ibidem, p. 100.

${ }^{61}$ G. Pérez de Ledesma, op. cit., p. 103.

${ }^{62}$ Ibidem, p. 104.
} 
Ormaza llama «buen estilo». Para nuestra suerte no se va por las ramas. En el capítulo XVII precisa que este debe ceñirse a siete criterios: 1) buscar la novedad de sentencias, no de palabras; 2) de las uniones agudas derivará siempre la originalidad de las palabras comunes, y ello gracias al concepto, al empleo de un vocablo o de una metáfora; 3) la oración tendrá un esplendor ajeno a las lentejuelas y al destello de la plata y el oro; 4) los latinismos son admisibles solo cuando el español carezca de términos equivalentes; 5) incurriendo en una paradoja, como suele ocurrirle en la práctica, Ormaza asume el modelo valdesiano al decir que «los eruditos no pueden dudar de que el uso es árbitro de las palabras»; ${ }^{63}$ 6) nuestra lengua alcanza lo mismo que la latina en sentencias, figuras y metáforas, contando además con equívocos, alusiones, hispanismos y gracia singular para las contraposiciones; 7) de luminosa modernidad -creo que no se ha señalado-, su adopción de «voces peregrinas», o sea, de latinismos y extranjerismos; pero en virtud no solo de su falta en castellano sino de la «cadencia» que sean capaces de entablar con las voces peninsulares. Un criterio prosódico, por así decir, que no he hallado en ningún otro Arte de la época y que apenas asoma por las gramáticas del Siglo de Oro. De hecho, Ormaza lo utiliza a propósito de la «brevedad clara», pero no cuando trata sobre la adopción del léxico no patrimonial. En el capítulo XX, concluye que «aquellas cláusulas estrechas mal se pueden decir con bizarría, y si la cadencia no lisonjea el oído, no hallará la razón entrada para mover». ${ }^{64}$

Provisto de estos rasgos, el jesuita estratifica en géneros el «buen estilo», que Velasco dejará in fieri, a pesar de la aporía -al confundir géneros con estilos- de ordenarlo igual que Pérez de Ledesma. Ormaza, siguiendo a Aristóteles y Cicerón, determina en el capítulo XVIII de la Censura que existen el grandílocuo, todo gravedad y altura, si bien poco común en la oratoria eclesiástica; el sumiso o tenue, que solo se preocupa de "pensar bien y explicarse con viveza», sin desdeñar los modos vulgares; y el tercero, que media entre ambos y llaman templado. ${ }^{65}$ Es fácil inferir que tanto el capítulo como la clasificación de Ormaza sirven de calco a los del colombiano.

Volvamos un instante sobre la debilidad más acusada de las páginas del Censor: el incumplimiento de sus propias leyes. ${ }^{66}$ Lo resumo: la proposición de los sermones se corresponde con el estilo sumiso, la ponderación del exceso con el templado y la invectiva con el grande. El problema principal de tanta rigidez es que muchas veces

\footnotetext{
63 Ibidem, p. 107.

${ }^{64}$ Ibidem, p. 114.

65 G. Pérez de Ledesma, op. cit., p. 108.

66 Según A. de Bondía, op. cit., fol. 14, «no diciendo cosa con seguridad, a cada periodo se contradice, que es lo que los oradores y jurisconsultos llaman ambigüidad». Y repite: «hace, pues, el licenciado Faquín increíble su tratado, y sin embargo quiere que lo creamos, contradiciéndose a cada paso y apenas ajustando un precepto con otro; y deshaciéndolo todo en la práctica o ejecución» (fol. 19).
} 
la teoría de Ormaza se desvanece como un castillo de naipes. Velasco es consciente de que aquella división de los clásicos no se hizo «para que el rectórico predicador hiciese unos sermones con un estilo y otros con otro, como se engañó el "Censurador de la elocuencia", que trae ejemplar de sermones distintos para cada género de estilo». ${ }^{67} \mathrm{Un}$ detalle que ya le había recriminado Céspedes en Trece por docena. No se trata de hacer sermones exclusivos, sino de que los géneros («sumiso», «templado», «grande»...) se acomoden en discursos con «variación»; o sea, usando «del remiso en su lugar, del blando cuando es tiempo y del magnílocuo cuando conviene». ${ }^{68}$ La glosa del bogotano suena tan obvia que corre el riesgo de parecer banal. No obstante, en otra coincidencia poligenética, y aunque Velasco no posea la gracia de Céspedes, cuyo juicio copio a continuación, apenas hay diferencias entre ellos. Escribe el pucelano:

Dice al principio del capítulo 18 que el estilo grandíloco es todo gravedad y altura, sin abatirse nunca, ni aun humanarse, y que este estilo solamente viene bien en un panegírico de la muerte de un príncipe, en una bienvenida de un rey, o en alguna muy célebre festividad. Pregunto agora, ¿este panegírico del príncipe ha de ser todo exclamaciones y todo rayos? Claro está que no, porque eso sería pregonar y no predicar. [...] Y luego, particularizando, dice que la enseñanza, la narración, explicación de lugares y misterios, pide estilo sumiso; las ponderaciones, exornaciones de erudición y descripciones, piden el templado; luego, para arrebatar el auditorio, para reprehenderle y exhortarle se requiere el estilo grandíloco. Pues colijo aquí evidentemente que si este panegírico del príncipe no ha de ser impropio ni cansado, habiendo de tener, como hemos visto, narraciones y ponderaciones, es fuerza que en ellas use de los estilos sumiso y templado, pena de impropriedad. [...] ¿Pues para qué dice que el sermón desta ocasión es el empleo proprio del estilo grandíloco, supuesto que, no habiendo de ser improprio ni cansado, es fuerza que los encierre todos? [...] Dijimos [...] que cualquiera materia es capaz de cualquiera de los estilos. De suerte que puede haber narración tenue, templada y alta, exornación y reprehensión de la misma suerte. ${ }^{69}$

La verdad es que Céspedes sabe poner como nadie los puntos sobre las íes de su enemigo. Y su comunión de intereses con Velasco, por más que este no conociera Trece por docena, se revela más que afinada. No obstante, ambos autores yerran en un punto. Disparan sus flechas hacia el círculo más próximo al traspié retórico de Ormaza, pero no a su mismo centro: Pérez de Ledesma no niega en ningún capítulo que se puedan mezclar los estilos, por la simple razón de que en todo discurso hay proposiciones, ponderaciones y reprehensiones, trasuntos estructurales de los géneros ya descritos. Lo paradójico, el flanco débil de su argumento, es que Pérez de Ledesma, al igual que Velasco cuando desmenuza los hilos que sostienen el sermón, consideraba que unas partes admiten solo una forma elocutiva y las demás el resto.

${ }_{67}$ M. de Velasco, op. cit., fol. 47. A. Egido, «La 'hidra bocal'. Sobre la palabra poética en el Barroco», Edad de Oro, VI (1987), pp. 79-183, se ha ocupado por extenso de este asunto y de la tendencia barroca a la amplificación y a la variedad interna.

68 M. de Velasco, op. cit., fol. 47.

69 V. de Céspedes, op. cit., p. 205. 
Podría discutirse. Pero también es lícito creer que con esta normativa los fieles sabrían a qué atenerse en cada momento de la homilía. Quizá el verdadero problema se origina cuando Ormaza afirma que el paso entre los estilos -que Céspedes y Velasco llamaron «variedad»- se producirá «tan secretamente que solo quien sepa los primores de la elocuencia los distinguirá enteramente». ${ }^{70} \mathrm{Y}$ es que sobre este asunto, tan esotérico, no se pronunciaron ni el nieto del Brocense ni el animoso franciscano.

Se trata de la principal «herejía ormaziana»: la dificultad para separar los estilos, o sea, el paso de uno a otro, aun sin confutar la existencia de distintas clases. De hecho, si la mezcla resultaba de veras efectiva, como parece conceder el aragonés, aunque solo la perciban los rétores, ¿qué sentido tendrían en las artes praedicandi los capítulos que el mismo Pérez de Ledesma, Céspedes y Velasco dedican a la aplicación de los estilos? Quiero decir que si los estilos son tan escurridizos para los ingenios legos, ¿qué función asumen en el libro del bogotano los epígrafes acerca de la dispositio de la introducción, transiciones, discursos y conceptos, si, según Ormaza, son un misterio para buena parte de los fieles, incapaces de saber cuándo se cruza de unas a otros?

Estaríamos destruyendo así, de un plumazo, uno de los sellos de la homilética barroca: su condición de «espejo social», en venturoso sintagma de Francis Cerdan. ${ }^{71}$ Dicho de otro modo: los azotes contra la variedad estilística son muy gratuitos en los dos artes post-ormazianos; golpean sobre un Censor que no los merecía por las causas citadas sino por otra: su inconsistencia teórica.

Velasco declara que los estilos convienen en tres atributos sobre los que no se había pronunciado Ormaza: han de ser «naturales», «limados» y «pulidos». «Natural» es aquel que en general utilizan los «sabios», «entendidos», «prudentes»y «discretos». Opuesto frontalmente al «fingido», contrario a la naturaleza, el arte y la elocuencia. Para distinguir uno de otro, desarrolla una de las divisiones más sutiles de su obra, que de nuevo oscila entre los platillos de Pérez de Ledesma y Céspedes. Según Velasco, el que imita -una de las claves de su conceptismo- anda cerca de fingir. He aquí la antinomia entre poetas y predicadores. Los primeros no solo tenían licencia para fingir sino obligación de imitar. He aquí la famosa imitación compuesta de los versificadores

\footnotetext{
70 G. Pérez de Ledesma, op. cit., p. 111.

71 F. Cerdan, «La oratoria sagrada del siglo XVII: un espejo de la sociedad», Actas del IV Congreso Internacional Siglo de Oro (AISO) (Alcalá de Henares, 22-27 de julio de 1996), ed. Mª. C. García de Enterría y A. Cordón Mesa, Alcalá de Henares, Universidad de Alcalá, 1998, I, pp. 23-44. Algo semejante opuso A. de Bondía, op. cit., fol. 51: «Grandes noticias -dice nuestro licenciado- piden en el orador o predicador las muestras de serlo; pero sean ocultas y secretas, y después, con aquel magisterio o plenitud, con noticias digeridas, predique sin citas, que eso le basta para que todos lo entiendan, conozcan y veneren por hombre grande. Pregúntole con quién habla, ¿con el predicador que comienza o con los hombres hechos?».
} 
áureos. ${ }^{72}$ No en balde, Virgilio, para ser grande, tuvo que imitar a Homero, y los que siguieron al mantuano también lo tomaron como referencia. Pero el crédito de los predicadores viene de otro sitio: «deben valerse de los estilos según fuere el natural proprio de cada uno». ${ }^{73}$

Luego Velasco se sitúa en la órbita de Ormaza al defender la «novedad» de los sermones, huyendo de las copias y remedos de sus predecesores. Con todo, reconoce a los antiguos, con Gracián en primera fila, que esa voz propia solo se alcanza a través de la lectura y el Arte: «para este aliño debes buscar las voces, términos y vocablos más tersos y lucidos que pudieres: valiéndote de los números, figuras, colores, galas y tropos que la rectórica tiene y enseña, porque la creación que no se adorna con tropos y figuras, aunque vaya muy vestida de galas, saldrá desairada sin brío y $\sin$ alma». ${ }^{74}$

Poco después recupera la idea de «cadencia», que esta vez define como la «construcción más propia y natural de la lengua». El franciscano se distancia así de los gongorizantes, que no solo forzaban la sintaxis («usan de muchas anteposiciones de vocablos»), sino que separaron el nominativo del genitivo. Velasco insiste, pues, en una gramática esencialmente valdesiana: «el genitivo se ha de dejar a su dueño y no colocarlo tan lejos de quien lo rige que con dificultad se conozca». ${ }^{75}$

Lo último que pide al estilo es que sea «propio», una suerte de sinónimo de lo que los latinos y neoaristotélicos llamaron «decoro». Propiedad que atañe al hablante («persona que lo dice»), al contexto, al público («la ocasión en que lo dice»), al objeto («las cosas que se dicen») y al código («idioma en que se dice»). ${ }^{76}$ En definitiva, la calidad del sermón también depende de la varia condición de sus fieles, a los que debe amoldarse el orador: el estilo más pulido será para las cortes (sublime), el mediocre para el vulgo y el más llano para las aldeas (humilde). Tripartición que implica una lectura del vulgo sin las connotaciones peyorativas de hoy. Porque el «vulgo lector» y «oyente» era similar al que acudía a los corrales y leía los mismos libros que los discretos. ${ }^{77}$ Lo ha subrayado Dámaso Alonso:

\footnotetext{
72 Véase A. Vilanova, «Introducción» a Las fuentes y los temas del Polifemo de Góngora, Barcelona, PPU, 1992, 2 ${ }^{\text {a }}$ edición, pp. 13-51. Respecto a la imitación compuesta remito a la bibliografía de J. Lara Garrido en «La práctica de la imitatio. Modos y funciones en la integración creadora de modelos», Los mejores plectros. Teoría y práctica de la épica culta en el Siglo de Oro, Anejo XXIII de Analecta Malacitana, Málaga, Universidad de Málaga, 1999, pp. 169-207.

73 M. de Velasco, op. cit., fols. 49-50.

74 Ibidem, fol. 50.

75 Ibidem, fol. 52.

76 Ibidem, fol. 55.

77 Véanse O. H. Green, «On the Attitude toward the Vulgo in the Spanish Siglo de Oro», Studies in the Renaissance, IV (1957), pp. 190-200, y A. Porqueras Mayo, «Sobre el concepto de vulgo en la Edad de Oro», Temas y formas de la literatura española, Madrid, Gredos, 1972, pp. 114-127.
} 
Tal vez de los hechos sociales en que la literatura tiene intervención, los dos más importantes de aquellos siglos sean el teatro y la oratoria sagrada. Dejada a salvo la fundamental diferencia, los parecidos son grandes: fenómenos ambos atados a las categorías de tiempo y espacio, que buscan [...] el sacudir al público, y, por tanto, son un buen indicio para rastrear los móviles estético-afectivos de aquellas muertas generaciones; pero, además, fenómenos totalmente sociales y nacionales, para todo el pueblo (aunque en determinados casos podían dirigirse a solo una clase especial), que tenían una difusión para toda España. ${ }^{78}$

También conocemos que a los sacerdotes, desde antiguo, no les dolían prendas en mezclar sus fundamentos teológicos con anécdotas y sucedidos para satisfacer a toda clase de gentes. Del Corno ha observado, a propósito de Giordano da Pisa, que «per convincere il pubblico della verità di un concetto, il predicatore introduce eventi immaginari, possibili secondo l'esperienza quotidiana di chi ascolta; oppure incantevoli ipotesi che sembrano attinte a una memoria di fiabe e di frasi proverbiali; quando non si faccia addirittura ricorso a ipotesi assurde o alla figura dell' adynaton». ${ }^{79}$

Ormaza lo sugería con razones similares, si bien no es algo que le preocupe en exceso: «Hase de atender también la calidad del auditorio: a los rústicos, la vehemencia en el decir, las exclamaciones, los gritos, los mueven más que razones y, aunque vayan poco prevenidos de ellos, los afectos suelen hallar entrada. Los más ladinos sécanse a estos fervores no muy discretos, solo a la razón se rinden». ${ }^{80}$ Otra prueba de la vigencia de la noción de «fervor»y del interés del jesuita por armonizarla con la de «agudeza», así como «los frutos del ingenio con los del espíritu, quizá el único en su tiempo que tiene esta actitud conciliadora». ${ }^{81}$

Respecto a la propiedad del idioma, Velasco vuelve a manifestarse como un epígono de Pérez de Ledesma, pues evita los extranjerismos y las voces peregrinas para que no se pierda la pureza; aprobando, eso sí, las que han cobrado rango patrimonial y forman ya parte del sustrato castellano. Se muestra reacio, empero, a la introducción de vocablos: «entre los españoles se hallan bienquistos y pasan por propios muchos vocablos latinizados, griegos y arábigos antiguos; pero no tienen licencia para hacer agasajo ni admitir otros nuevos». ${ }^{82}$ Por tanto, «lo que ataca no es el estilo culto sino

78 D. Alonso, «Predicadores ensonetados», Del Siglo de Oro a este siglo de siglas, Madrid, Gredos, 1968, pp. 95-104 (p. 96). Véanse especialmente E. Orozco Díaz, «Sobre la teatralización del templo y la función religiosa en el Barroco: el predicador y el comediante», Cuadernos para la investigación de la Literatura Hispánica, II-III (1980), pp. 171-188, y J. Lara Garrido, «La predicación barroca, espectáculo denostado (textos y considerandos para su estudio)», Analecta Malacitana, VI (1983), pp. 381-387.

79 C. del Corno, «L'exemplum nella predicazione medievale in volgare», Concetto, storia, miti e imagini del Medioevo, a cura di Vitore Branca, Firenze, Sansoni, 1973, pp. 393-408 (p. 398).

80 G. Pérez de Ledesma, op. cit., p. 153.

81 A. Martí, La preceptiva retórica española en el Siglo de Oro, Madrid, Gredos, 1972, p. 254.

82 M. de Velasco, op. cit., fol. 58. 
el empleo de "palabras raras", "no genuinas" o "latinizantes" (lo que hoy llamamos precisamente "cultismos"); o sea, ataca el empleo de la "jerigonza" de la misma manera que en el teatro». ${ }^{83}$

El capítulo VIII del Arte se orienta a distinguir la misión de los estilos. Velasco considera que el remiso tiene por misión «enseñar, discurrir y filosofar, siendo muy a propósito para hablar con "agudeza"». El blando equivale a claro y, unas veces desnudo y otras vestido de galas (números, tropos, figuras), es oportuno para el deleite, las alabanzas y los vituperios. Por último, el magnílocuo sirve para persuadir. Nuevo plagio de san Agustín, primero, y de Pérez de Ledesma, después. Ahora bien, el colombiano acerca el remiso al magnílocuo, ya que ambos son sentenciosos: uno por su aticismo y el otro porque «exagera», «aclama» y «pondera», como los asianistas. En cierto modo, el primero sirve de lanzadera para los abusos del segundo. Ocurrencia que lo aleja de la clasificación de Ormaza, quien no solo no los relacionó sino que condenaba la falta de brío del uno y la hinchazón del otro.

\section{REPREHENSIÓN ANTI-ORMAZIANA}

Solo cuando ha expuesto las funciones de los tres estilos, Velasco se decide a medirlos con los de Pérez de Ledesma. Y no tarda en tachar de «viciosos» a los del aragonés, aunque «anden con capa de perfectos». A saber: 1) el pueril, que choca con el remiso; 2) el humilde, contrario al blando; y 3) el hinchado, opuesto al magnílocuo. La deuda con Ormaza es tan evidente que ahorro a los lectores la transcripción de unas páginas que duplicarían lo que ya han tenido ocasión de conocer. Mucho más seductor, pues el jesuita apenas lo dibuja, es el razonamiento del lugar de los estilos dentro del sermón, sus formas y propiedades (capítulo IX). Para Velasco, el estilo remiso tiene asiento en todas las introducciones mayores y menores, de manera que las sentencias no resulten «amontonadas» ni «indigestas», sino adecuadas para discurrir y filosofar al intento.

Lo novedoso es su dicotomía entre elocuencia y evidencia. Señala el bogotano que el remiso no debe deleitar como el templado, ni persuadir como el magnílocuo; por lo que su fin no es otro que «descubrir lo que estaba escondido y oculto al ingenio». ${ }^{84}$ Privilegia la res (evidencia) sobre los verba (elocuencia), oponiendo la idea de agudeza -proceso cerebral para tender lazos y correspondencias que iluminen el objeto- a la elegancia. Por ello, la forma del estilo remiso es «ir con ingenio y sutileza notando,

${ }_{83}$ F. Cerdan, «La emergencia del estilo culto en la oratoria sagrada del siglo XVII», Criticón, 58 (1993), pp. 61-72 (p. 66).

${ }^{84}$ M. de Velasco, op. cit., fol. 66. 
descubriendo, desentrañando y dando a conocer con discurso breve la naturaleza de las cosas».85

Velasco postula una retórica con pilares «sentenciosos», esto es, libres de polvo y paja. Para ello aclara que hay dos clases de sentencias: 1) las de cosas, intrínsecas en su propia naturaleza; 2) las de palabras, que surgen del artificio y disposición de los términos, de modo que si falta solo una se desvanece todo. El segundo grupo es más permisible, siempre que cumplan dos requisitos: 1) que no se hagan de continuo; 2) que tengan por «alma» alguna figura retórica, lo que da pábulo a la crítica de Velasco al estilo pomposo y la saturación de voces o neologismos. Acepta, sin embargo, cualquier audacia retórica que se sujete al Arte. Veamos sus autoridades: «te remito para el remiso a las Empresas políticas de Saavedra, a las obras de Quevedo, la Política de Dios, Fantasmas y Marco Bruto, etc. Aunque en este último trae las sentencias muy apretadas, que más parecen cadena que discurso». ${ }^{86}$

El estilo blando y significativo opera sobre los conceptos cuando los ata y los desata; con claridad -en el «qué» y en el «cómo»- y sin ir nunca contra el Arte, como hicieron los barroquizantes al oprimirlos con imágenes confusas. No en vano, el colombiano remeda la tan célebre como interesada dualidad de Cascales en sus Tablas poéticas a propósito de Góngora: según este, el «príncipe de la luz» había dejado paso con el Polifemo y las Soledades a la no menos falaz etiqueta de «ángel de tinieblas». Si bien nadie suscribe hoy dicha evolución, tan antojadiza como ilusoria, no es menos cierto que durante el último tercio del XVII caló en el imaginario de varios pensadores. Velasco no fue la excepción: «este estilo, por lo mucho que tiene de luz y poca amistad con las tinieblas, es estilo lucido y resplandeciente. Por la galas rectóricas con que se adorna, se llama gentil, galán y pulido». ${ }^{87}$

También Ormaza había acusado su huella, aunque a veces se desdiga:

Y los que no tienen tanta felicidad, aunque de grandes ingenios, hablan crepúsculos y son bocas de noche, cuando menos tenebrosos. Vemos con este achaque ingenios príncipes, pero desdicha es ser Príncipes de las tinieblas. Con todo, en estas misteriosas sombras solemos hallar gusto a leerlas [...] y cuanto más es la dificultad en sondarlas, más gusto quedamos de haberles topado el fondo. ${ }^{88}$

Huelga decir que San Agustín, modelo inmediato de ambos, como recuerda el Censor, tampoco expulsó a la oscuridad de sus sermones. No obstante, hay que precisar que utilizan el término de distinta forma: para el obispo de Hipona la oscuridad

\footnotetext{
85 Ibidem, fol. 67 .

86 Ibidem, fol. 92.

87 Ibidem, fol. 69.

88 G. Pérez de Ledesma, op. cit., pp. 113-114.
} 
procede solo de la doctrina (res), por lo que esta puede oscurecer el estilo. Nunca al contrario. Por tanto, considera que es positiva en su justa dosis, pues evita el hastío del auditorio ante lo que se entiende sin dificultad. Así, en el capítulo 14 del libro primero, el autor de las Confesiones establece la identidad entre los cirujanos y los predicadores, mientras que en el sexto del segundo insiste en que «se ha de afectar algunas veces la oscuridad. [...] Prueba esto con las misteriosas obscuridades en que muchas veces late la Eterna Luz». Finalmente, en el quinto del libro cuarto, encareciendo mucho el ingenio, la elocuencia y la discreción, José de Ormaza añade que «sin esto será la sabiduría tan inútil como perjudicial». ${ }^{89} \mathrm{Y}$ precisa:

Mejor la sigue Quintiliano, que dice: como el agua del río caudaloso, corriente y claro; no parece consiente en esto nuestro siglo que osa hablar oscuro porque nadie gusta de claridades. Mas hay que distinguir: unos parecen claros, aunque sea poco limpia el agua, porque llevan poca; otros son obscuros de profundos. Más claro es Pisuerga que Esgueva; con todo, en este se ven las guijas, y en aquél ni aun las peñas. $^{90}$

Dos ríos -Pisuerga y Esgueva-, satirizados por Góngora y Quevedo, que invitan a deducir que el párrafo de Ormaza, un predicador, sobre la claridad y la oscuridad de los sermones no es muy distinto al de los panegiristas y detractores de don Luis a raíz de la batalla que encendió la «nueva poesía». Jáuregui escribía en su Discurso poético que «no es ni debe llamarse oscuridad en los versos el no dejarse entender de todos, y que a la poesía ilustre no pertenece tanto la claridad como la perspicuidad. Que se manifieste el sentido, no tan inmediato y palpable, sino con ciertos resplandores no penetrables a vulgar vista: a esto llamo perspicuo y a lo otro claro». ${ }^{91} \mathrm{Y}$ Vázquez Siruela, coetáneo de Ormaza, se preguntaba por las mismas fechas (1645-1648): «Quisiera yo saber de dónde han colegido que es obscuridad ésta que reprehenden, y no antes abundancia de luz. Porque el bailar de los ojos, si eso dan por señal, el desaparecerse de los objetos, son indicios poco vehementes; pues nadie ignora que esos efectos tanto suelen causarse de la copia de luz, como de la falta». ${ }^{92}$

Según Velasco, las salidas de los conceptos son, en cambio, el lugar natural para el estilo magnílocuo, junto con los finales de discurso y el cierre del sermón. También incide en las «acomodaciones», «epílogos»y «reducciones», porque en estas partes «se supone que ya está convencido el entendimiento con las razones y discursos del [...]

89 Ibidem, p. 57.

90 Ibidem, p. 65.

91 J. de Jáuregui, Discurso poético (advierte el desorden y engaño de algunos escritos), ed. M. Romanos, Madrid, Editora Nacional, 1978, p. 215.

92 S. Yoshida, «Martín Vázquez Siruela: Discurso sobre el estilo de don Luis de Góngora. Presentación, edición y notas», Autour des Solitudes. En torno a las Soledades de Luis de Góngora, Anejos de Criticón, 4, ed. Francis Cerdan et Marc Vitse, Presses Universitaires du Mirail, 1995, pp. 89-106 (p. 99). 
remiso». ${ }^{93}$ Una vez trazado el perfil de los estilos, solo falta rematar que el magnílocuo gasta más tiempo que todos, el blando mucho menos que el remiso y este último menos que ninguno. Lo que lleva a concluir que para Velasco la buena retórica prescinde de las descripciones morosas, porque lo nuclear es el discurso y la persuasión.

La alargada sombra de Ormaza sobrevuela por el capítulo X: «Elocuencia cristiana». El colombiano indica que consiste en «saber gobernar bien y con propriedad los tres géneros de estilo», teniendo en cuenta que existe un género de elocuencia, al decir de san Agustín, que no lo enseña Cicerón ni ningún otro maestro. Releyendo a lo cristiano el furor platónico, concede que el Espíritu Santo es responsable de brindar el «de qué» y el «cómo» se ha de hablar. Y de nuevo a la zaga de los antiguos textos citantes, advierte que los predicadores «mozos, ancianos, graves, doctos o santos, que aún no han recibido de la mano de Dios este supremo género [...], prediquen la que deben saber y enseña san Agustín. Y si esta aún no la saben, porque la desprecian, no prediquen hasta que la sepan». ${ }^{94}$

Pero su tratado, que dice inspirarse en la Doctrina cristiana, omite en cambio el último párrafo del Padre de la Iglesia sobre la «elocuencia de mozos», para quien esta sería fallida si los obligan a parecer viejos, avanzando así la libertad homilética -sin lugares ni fuentes- que Pérez de Ledesma refinó trece siglos después. De igual manera, el sabio latino piensa que resultaría grotesco que los viejos quieran parecer mozos. Mas el hálito de los antiguos se cierne otra vez sobre el bogotano, que apela indirectamente a Ormaza cuando señala la inconsistencia entre la teoría del aragonés y sus sermones:

los hombres graves y doctos también incurren en desaseo de términos y palabras mientras procuran desviarse de lo muy afectado de algunos falsos elocuentes. En esto no andan acertados porque si son doctos y conocen los yerros ajenos, enmiéndenlos en sí mismos. [...] ¿Por qué un doctor grave, lleno de títulos y de letras, ha de predicar como los otros que predican sin arte? Si el que debe enseñar a los otros, quitándoles sus yerros, los imita, ¿quién será aquel que los enmiende a todos? ${ }^{95}$

No hay duda de que Ormaza vuelve a ser el blanco, pues el Censor se había quejado ya de que "grandes ingenios, cultivados de no vulgares noticias y prendas de púlpito, eligen el descrédito de estériles troncos antes que el aplauso de floridos y fecundos en este campo de la elocuencia, donde la llaneza es caída, lo levantado cuesta, y precipicio lo que se juzga eminencia». ${ }^{96}$ Ahora bien, Velasco, aunque coincida con el

93 M. de Velasco, op. cit., fol. 71.

94 Ibidem, fol. 76.

95 M. de Velasco, op. cit., fols. 79-80. Véase F. Herrero Salgado, op. cit., pp. 419-436.

96 G. Pérez de Ledesma, op. cit., p. 49. 
capítulo XV («Del afectado lacónico») de la Censura, defiende el Arte y no termina de abrazar el programa de Ormaza. Solo así se puede valorar su fe en aquellos que procuran que «todo lo leído, como los diversos alimentos, se convierta en sangre y nervios del discurso» hasta hacerse «cuerpo propio». ${ }^{97}$ Luego Velasco critica a Pérez de Ledesma sus licencias concionatorias. Igual que Ameyugo, otro de sus modelos, cuando escribía que "grande estrago y calamidad ha corrido por la oratoria cristiana, como lo notan ya muchos en sus rectóricas sagradas». ${ }^{98}$

En síntesis: durante el vaivén teórico por el que balancea su pluma, Velasco se muestra más afín a Ormaza que a Céspedes cuando asocia la elocutio a las partes de discurso y por ello al contenido. Para el vallisoletano ambos discurrían completamente aislados. De ahí que restringiera el ornato al exterior de las palabras; reclamando que «el concepto sea lo principal y no todo se reduzca al estilo». La antítesis de lo argüido por el aragonés. No obstante, López Santos acierta al traducir que «esta argumentación solo es sólida en apariencia; pues Céspedes arranca de una noción de estilo que no es la de Ormaza. Este opina, en efecto, que "el estilo no es solo la parte principal, sino el todo de la oración". Pero, en un alarde de modernidad, da esta acertada fórmula: "Yo no distingo el estilo de la buena razón concertada en palabras". Al fundir de este modo concepto y estilo, fondo y forma, cae por su base buena parte de la argumentación contraria». ${ }^{99}$

\section{LA ACTIO}

También decorosa con los clásicos es su lectura de la «elocuencia de semblante llamada gesto», adaptada a cada estilo: apacible, mansa y autoritativa, en el remiso; serena, afable, amistosa y cortesana, para el blando; y majestuosa, grave y severa, aunque pueda ser también «cariñosa con gravedad», cuando se refiere al magnílocuo. Entresaco un ejemplo del crédito que Velasco otorga a la actio:

Cuando algunos te enseñaren que es buena acción y lucida correr la mano derecha desde lo alto del hombro siniestro cuando se empieza la cláusula, y acabar juntamente con ella en frente y poco más abajo del hombro derecho, si a esta regla no añaden otra advertencia la dejaron general y dañosa: porque dicha acción, aunque es muy lucida, solo se puede valer de ella en el estilo templado y numeroso, porque en él corren las cláusulas, y puede ir la mano al mismo paso que ellas fueren. Pero si el estilo fuere remiso, agudo y eficaz, o sublime y vehemente, irá el estilo a pausas y la mano corriendo con improporción. [...] La mano siniestra jamás hable sola sin compañía de la otra, si no es en ocasiones de desechar algún

\footnotetext{
97 Ibidem, p. 55.

98 M. de Velasco, op. cit., fol. 82.

99 L. López Santos, «La oratoria sagrada en el Seiscientos. Un libro inédito del P. Valentín Céspedes», Revista de Filología Española, XXX, 3-4, 1946, pp. 353-368 (pp. 361-362).
} 
golpe que amenaza; o cuando vas hablando de color rectórico por transición tocando como de paso, que entonces jugar de la mano siniestra será destreza. ${ }^{100}$

Es notorio que uno de los rifirrafes entre Ormaza y Céspedes atañe a la actio. Para el Censor, a diferencia del vallisoletano, que apoya a ultranza la representación, la teatralidad debía sacarse de los púlpitos. ${ }^{101}$ Los gestos ni siquiera atraen a Pérez de Ledesma que, fiándolo todo a sus detalladas «pinturas», apenas ofrece datos de la técnica interpretativa de los predicadores. Solo alguna pincelada al final de cada estampa. Por ejemplo, en la «Idea del murmurador maligno y chismoso», evoca que «la astucia frecuente es poner semblante de chanza y cuento al chisme porque parezca sirve al entretenimiento y no al odio». ${ }^{102}$

Considero -tampoco se ha dicho- que su disputa no se cifra en si es mejor representar o no, sino que descansa, como muchas de las cuestiones que releyó Velasco, más en una asimetría de la dispositio y menos en un problema de la actio. Escribe Céspedes: «su principal invectiva no mira tanto a esto cuanto al mucho tiempo que en esto se gasta en púlpitos, que dice que son, de las cuatro partes del sermón, las tres, y que se cuentan historias que las saben todos los niños». ${ }^{103}$

Velasco, en su valoración de la tramoya del cuerpo, está más cerca de Salcedo de Aguirre, por citar un caso temprano y poco leído incluso en su época. No en vano, solo Ameyugo se hizo eco de la preceptiva del jiennense:

El cuerpo debe estar siempre derecho sin torcerlo a parte alguna. Será mucha fealdad recostarse de un lado sobre el púlpito, y aun poco respeto a los oyentes. Debe convertirse a una y otra parte sosegadamente, sin aceleración, mirando a diferentes partes para cumplir con todos. [...] El brazo derecho es el que ordinariamente se mueve, el cual no se debe levantar sobre la cabeza ni derribarle debajo del pecho o cintura, ni aun la mano. [...] De la siniestra sola no se usa, pero acompañada con la diestra hace galanas a[c]ciones. [...] No es decente dar palmadas con ambas manos ni traer la una demasiadamente arguta o ligera, ni herir con la mano el pecho propio, ni tener encorvado el brazo hacia sí propio. ${ }^{104}$

\footnotetext{
100 M. de Velasco, op. cit., fols. 89-90.

102 G. Pérez de Ledesma, op. cit., p. 163.

103 V. de Céspedes, op. cit., p. 94.

104 G. Salcedo de Aguirre, Pliego de cartas, fols. 201-204.
}

101 Según P. Tanganelli, «"En la gloria en donde el lenguaje es ver”: técnicas de visualización en el sermón barroco», incluido en este número de Lectura y signo, "Ormaza es el portaestandarte del sermón conceptuoso y de unas visualidades caleidoscópicas, mientras que Céspedes defiende la tradicional techné que combina evidentia verbal y actio teatral». También A. de Bondía, op. cit., fol. 118, huyó de convertir el púlpito en escenario: «algunos ignorantes, que como ni tienen razón de que valerse ni entienden lo que predican, dan golpes desmesurados en el púlpito, palmean a cada pausa, tuercen el cuerpo, desquician la voz y hacen otros meneos y gestos tan exorbitantes que muelen al auditorio». 
Lo mismo aconseja Juan Rodríguez de León en El predicador de las gentes San Pablo, de la misma generación que el colombiano: «Será culpable solecismo el de los que fueren diciendo con las palabras lo contrario que señalaren las acciones. [...] Y no parezca zurdo el predicador; acompañe con la diestra -no con la siniestra- la significación del concepto más comúnmente». 105

A Velasco no le tiembla el pulso a la hora de fijar los tipos de talentos en las catedrales: 1) aquellos cuyo natural los inclina a representar como comediantes. Muy denostados, son «la farsa y la abominación del pueblo»; 2) otros que representan con estilo y son llamados «hombres de gran talento»; 3) los que tienen talento pero no lo ejercitan, porque ignoran sus cualidades y «siguen rezando como ciegos»; 4) los que tienen «natural de rezar»y es imposible que el arte los enmiende ${ }^{106}$. Esta clasificación y las anteriores citas, contrarias a la Censura, validan la categoría de la actio, subrayada por Ledda cuando examinaba la «utilización de objetos auxiliares (calaveras, crucifijo, corona de espinas...) para hacer concreto el paso de lo invisible a lo visible» ${ }^{107}$.

Los capítulos acerca de las cualidades del estilo remiso son amplificaciones de lo analizado; si bien Velasco, en su estricto cartesianismo, las concreta en siete y aduce la autoridad de Nájera y sus «sentenciosos sermones»: discurso, sentencias, números, hermosura, realce, claridad y brevedad. ${ }^{108}$ Destacan sus notas acerca de los modos de introducción en los que se rentabiliza dicho estilo: 1) cuando no se precisa más que una cosa de la historia, o un texto relativo a ella, no hay que usar la «narración», sino una «sentencia» sobre la que se ahondará hasta aclarar la dificultad o el concepto; 2) si se necesitan dos o tres textos, hemos de acogernos a la narración, desatando las cuestiones (que serán varias) y fluyendo hasta llegar al núcleo principal. Cuando se opte por esta segunda, el párroco preverá que también hay dos clases de narración: 1) la «magistral», que supone la necesidad de hacer efectivas las partes esenciales de la retórica; y 2) la «descriptiva y elegante», para públicos formados y faltos no tanto de instrucción cuanto de persuasión. Llegados a este momento, conviene ser prudente, porque el orador se desacredita cuando se paga de las narraciones descriptivas y las vende como admirables. Para ambas da cuenta, respectivamente, de dos tipos de pronunciación: la sosegada y la presurosa.

$\overline{105}$ J. Rodríguez de León, El predicador de las gentes San Pablo. Sciencia, preceptos, avisos y obligaciones de los predicadores evangélicos con doctrina del Apóstol, Madrid, M. de Quiñones, 1638, fols. 214-215.

106 M. de Velasco, op. cit., fol. 96.

${ }^{107}$ G. Ledda, «Predicar a los ojos», Edad de Oro, VIII (1989), pp. 129-142 (p. 134). Véase de la misma autora «Forme e modi di teatralità nell'oratoria sacra del 600», Studi Ispanici, 1982, pp. 87-106.

108 M. de Velasco, op. cit., fol. 101. 


\section{SENTENCIAS, LUGARES Y DESCRIPCIONES}

El lugar que tienen en el sermón las partes esenciales de la retórica (invención, elección, disposición y pronunciación) deja paso al comento del tejido de las partes materiales: 1) introducción; 2) orden de discursos; 3) orden y lugar de los conceptos. Me refiero a la «forma de provecho». El Padre Velasco se apresta a razonar el papel de la enseñanza en el sermón, flecha malévola que pone en tela de juicio una de las teorías de Ormaza. Según el colombiano, «hacía la guerra el «Censurador de la elocuencia»; andábase a destruir lugares con título de enmendar yerros; en notando el vicio, daba la sentencia contra el lugar en que lo hallaba colocado, siendo el lugar de la elocuencia, y el vicio de quien la ofende: no es culpa el lugar, sino lo mal puesto». ${ }^{109}$

Para entender su postura hemos de acudir a los antepasados sermonarios que nos concitan. Pérez de Ledesma reprochaba que «de uno, porque ensartó muchos lugares, dicen: “¡Grande hombre!; en la uña tiene la escritura”. Otros por esto mismo le tachan de popular». ${ }^{110} \mathrm{Y}$ sentencia sin ambages:

Es predicar al uso no hilar nada de suyo. Proponen en dos palabras el asunto y luego: ¡vengan Jacob, Moisés y David a probarlo! Que, como si fueran gente ruin, han de ser testigos pagados para cuanto se le antoje el predicador. [...] Gástanse de las cuatro partes del sermón, cuando menos las tres en contarnos historias que no ignoran los niños. [...] ¿Cuál, pues, sermón vemos sin vestirse destos lugares de centón, que donde quiera se hilvanan? [...] ¿Cómo ha de seguirse esta carrera, andando casi siempre con muletas? Así llaman los lugares los que más cojean de esta landre. ${ }^{111}$

Velasco incidirá en su Arte sobre las nociones de pertinencia, posición y decoro, reprobando todo lo que se aleje de ellas, pero no el uso de lugares en sí mismos. Nótese, sin embargo, el distinto sentido del sustantivo, que pudiera equivocarnos. Para Ormaza los «lugares» son citas de la Biblia, de los Padres de la Iglesia o de poetas y oradores de mérito en los que reposa, a veces demasiado, la homilía del abad de turno. El fraile de Santa Fe, en cambio, también escribe «lugar» como posición de las partes esenciales de la retórica dentro de las materiales y, por decoro, el estilo pertinente a cada cual: «tiene pues la enseñanza su lugar propio [...] en todas las introducciones mayores y menores, y en todas aquellas partes en donde se hallan los estilos remiso, y el blando, claro y desnudo». ${ }^{112}$ Respecto a la contigüidad entre el estilo y las partes discursivas, el Censor aducía:

\footnotetext{
109 M. de Velasco, op. cit., fol. 113.

110 G. Pérez de Ledesma, op. cit., p. 51.

111 Ibidem, pp. 67-69. L. López Santos, op. cit., p. 358, mantuvo que el centro de esta querelle es la antinomia entre «autoridad» (Céspedes) y «razón» (Ormaza).

112 M. de Velasco, op. cit., fol. 113.
} 
la mayor parte de la obra es comenzarla bien. A un buen empeño todo conspira; el discurso, las palabras, las exornaciones vienen rogando a un buen intento y, en siendo este abatido, por más que lo procure levantar la Elocuencia, se quedará caído. Cuanto más le asean peor: parece un rústico; al discurso bien nacido las galas le buscarán. ${ }^{113}$

Un párrafo que el bogotano no supo evaluar o interpretó de forma tendenciosa. A su juicio, «cierto maestro dejó escrito en su Arte que el estilo realzado -magnílocuo quiso decir- era muy a propósito para las introducciones; mas yo, que no profeso ser censurador, ni lo estilo, digo con llaneza que no cabe en el arte esta doctrina; [...] sino que procede siempre de menor a mayor. La palma primero besa el suelo de que nace». ${ }^{114}$ Muy injusta es la atribución de este fallo a Ormaza, que solo defendía «no comenzar abatido». Sin excluir el uso del estilo blando, ni siquiera del sumiso, para evitar justo aquello que Velasco le recrimina. Eso sí, conviene «no asearlo tanto», uno de los rasgos del grandílocuo, porque el oropel léxico-sintáctico propicia el efecto contrario: lo rebaja a rústico.

Más plausible, porque no consta en el Censor ni en Céspedes, es su aviso de que el predicador debe tener un punto de cómico y otro de loco. Pero, obviamente, esos dos granos de sal no hay que gastarlos en las introducciones, sino guardarlos como «oro en polvo» para los cierres en estilo grandílocuo. Otro fleco un tanto espinoso es que, según el franciscano, la enseñanza se puede llevar a cabo sin sentencias, porque estas son un fatuo condimento de la elocuencia.

Si nos detenemos en la segunda parte esencial de Velasco, el «deleitar» posee mayor importancia que antaño, confluyendo otra vez con Ormaza, abogado impenitente del estilo (de la elocutio), aun cuando el bogotano se oponga al uso de pinturas y descripciones:

hay una turbamulta de sectarios que están persuadidos y obstinados a que esta parte de la retórica consiste en el lenguaje afectado. Una cosa es lenguaje afectado y otra estilo con arte, porque este es natural. [...] Ya que se intenta agradar al auditorio, ¿quién le dijo a estos que el todo estaba en sus pinturas y descripciones? $Y$ que la mayor gala era sacar cada rato una mariposa, ya de cristal ya de nieve y ya de fuego? Válgate Dios por mariposa esencial. Señores, ¿no me dirán de dónde sacan tantas, que nunca faltan ni jamás se agotan? Yo quise una vez hacer un sermón todo variegado de distintas y bizarras mariposas. Y como la Sagrada Escritura es fuente de todo, acudí a ella, y hallé en el Éxodo ranas, mosquitos, ratones; en los Salmos, arañas; en los Proverbios, hormigas, y en el Apocalipsis, langostas. Pero en toda la Sagrada Escritura [...] no se hallará una sola mariposa. ${ }^{115}$

\footnotetext{
$\overline{113}$ G. Pérez de Ledesma, op. cit., p. 144.

114 M. de Velasco, op. cit., fol. 114.

115 Ibidem, fol. 119. Según G. Pérez de Ledesma, op. cit., p. 62, «más desdice el orador eclesiástico el afeite que la suciedad. Más le quieren los cuerdos vestidos de sayal que de exquisitas telas, bien que uno y otro es indecencia». Y añade: «quien solo en la abundancia de palabras sonoras ponga la fuerza de su estilo
} 
Se trata de uno de sus encontronazos con la camarilla de Ormaza. Aunque las descripciones netamente conceptuosas irrumpen en las artes praedicandi desde 1648, según ha estudiado Tanganelli, no perdamos de vista que el pionero en atisbar la solvencia de las artes plásticas (emblemas, jeroglíficos) en la conción fue Salcedo de Aguirre en su Pliego de cartas (1594): «será asimismo de mucha utilidad en ocasiones que lo pida traer un jeroglífico, emblema o empresa y aun alguna fábula de Isopo o de otro autor antiguo». ${ }^{116}$

A grandes rasgos, Pérez de Ledesma critica a los oradores que «gastan todo su aseo en afeitar la descriptio». ${ }^{117} \mathrm{Y}$ recuerda que entre sus funciones se cuentan la de hacer ameno el discurso y mover al auditorio. Luego la ekphrasis ya no es para él una simple figura retórica, sino una techné compositiva:

"La descripción es hoy no solo figura, sino todo el pasto y baraja de los Predicadores; así, bien merece que se habla de ella a solas". Però se Ormaza stima che i sermoni barocchi siano essenzialmente descrittivi non è tanto perché la descriptio a volte occupa davvero tutti i punti o cabos del sermone quanto perché la ritiene l'unico parametro in grado di misurare l'effettività della predica e le capacità retoriche dell'oratore sacro. Ormaza è dunque, come d'altro canto attestano anche le pinturas verbali que introduce nella seconda parte della Censura, uno dei pochi teorici che non richiede che la descrizione dilettevole sia breve, ma anzi elogia una descrizione iperdettagliata. ${ }^{118}$

El Arte de sermones, aun cuestionando dicha técnica, con la que Pérez de Ledesma abrocha su tratado, nos ofrece una pista precisa que no solo informa de la recepción de la Censura en aquellos años sino que da noticia de la existencia de una continuación en la que Ormaza se retractaba, siquiera parcialmente, de lo publicado en 1648:

el «Censurador de la Elocuencia» fue maestro de pinturas cuando no tenía canas. Llegose la edad con ellas y el desengaño. [...] En la «Introducción de los lugares» (son palabras suyas de enmienda, que imprimió en Madrid, año de mil seiscientos y sesenta y siete), procuró luego ir al caso del picante, y excusar prosa: "que ha mucho busco lo vivo y colgué lo pintado". [...] Pues si alguno hasta aquí siguió al «Censurador» en el estilo vicioso y de paja, imítele también después de convertido y váyase al grano. ${ }^{119}$

Tanganelli confirma que Velasco alude al Grano del Evangelio en la tierra Virgen Christo, Seminario de toda enseñanza, limitada por averla puesto en estas pajas (1667), en cuyo prólogo constan las palabras que repite el bogotano. Empero, tampoco hay certeza de que Ormaza reniegue de la Censura, pues en esa secuela, pocas líneas después, el jesuita

\footnotetext{
hará un charlatán y tendrá la menor parte» (p. 82).

116 Ibidem, p. 179.

117 Ibidem, p. 58.

118 P. Tanganelli, La descrizione, pp. 60-61.

119 M. de Velasco, op. cit., fols. 122-123.
} 
anuncia que pronto saldrá una traducción escoliada del Thesauro manual en la que «se hallan ventajosas pinturas de los sujetos, y acciones memorables de la Escritura». ${ }^{120}$ Como no podemos fundarnos en conjeturas, del Arte de Velasco se deduce que hay dos modos de descripción: a) la lógica, referida a la definición de la cosa y responsable del estilo sentencioso, genuino, significativo y agradable; y b) la retórica (perífrasis), más dilatada, que camina sobre metáforas y elegancias. No entra a detallar las cuatro clases de las que hablaba Ormaza: imagen, eficción, notación y demostración. Quizá porque, en tanto que «conceptuosas», sinónimo de «encrespadas» para él, se desviaban de lo que el franciscano llamará «concepto», donde la brevitas es innegociable. Se diría que a la luz de este distingo Velasco se muestra muy aristotélico: contrapone la lógica o definición (horismós) a la citada perífrasis. La taxonomía de Ormaza, que a primera vista podría parecernos más compleja, se basa tan solo en la res u objeto representado, bien alejada, pues, del planteamiento filosófico del colombiano.

Leamos la definición que da este último del deleite: «suspensión, gozo y descanso del entendimiento en aquellas cosas artificiosas que va mirando y entendiendo de nuevo. [...] Nace de la armonía que todas hacen cuando están puestas, o se van poniendo con propiedad en sus lugares». ${ }^{121}$ Es básico dividir todas las materias con mucho ingenio y probar la división con «agudeza de conceptos». Un criterio donde la «fantasía» marca las diferencias: «es la fantasía ficción retórica de rectórico lugar: cuando el Predicador con valentía de ingenio y fundamento en el arte finge lugar propio para alguna parte de la Rectórica que allí no le tiene». ${ }^{122}$

Por tanto, a tenor de Velasco, la invención poco o nada tiene que ver con la fantasía; antes bien se separan en que la primera busca y halla las cosas para sus lugares propios, mientras que la segunda traslada esos descubrimientos de los lugares propios a los impropios, fingiéndoles una naturaleza correlativa y hasta una causalidad que «según es la razón, ocasión y tiempo a que las trae, parecen propias, y como allí nacidas». ${ }^{123}$ Otro de los puntos en los que nuestro clérigo coincide con Ormaza es en la huida de la turbamulta de lugares, pues no se deben gastar «tantas ponderaciones en lugar adonde no las permite la elocuencia». ${ }^{124}$ De hecho, el que abusa de ellas «no juega de fantasía». Su regla no admite medias tintas: «puede ir el predicador variando

\footnotetext{
120 P. Tanganelli, La descrizione, p. 62.

121 M. de Velasco, op. cit., fol. 125.

122 Ibidem, fol. 139.

123 Ibidem, fol. 140.

124 Ibidem, fol. 141.
} 
por todo el sermón de fantasías con licencia que tiene para valerse dellas en todos los lugares y partes menores. Pero no en las partes mayores y principales». ${ }^{125}$

El aprendiz de predicador habrá de imitar el Arte de sus maestros, no así las «fantasías», entendiendo la palabra ahora no solo como facultad, sino también, en la línea de Longino, como descripción o 'imagen fantástica'. Con lo que asesta un claro rejón a las pinturas imaginarias de Ormaza, entendidas como aquellas que «se construyen a partir de una semejanza conceptuosa (como diría Gracián); o sea, las que utilizan un símil ingenioso, planteando a menudo una especie de enigma o de emblema. ${ }^{126}$ Recordemos que Bondía ya había hecho mala sangre del Censor a causa de tales estampas. Y lo mismo Céspedes: «Los herejes procuraban con la elocuencia ganar el oído, pero el intento era pervertir el ánimo. Las palabras con que se introducían eran compuestas, pero la doctrina que debajo dellas se contenía era perversa y de propósito contraria a la fe». ${ }^{127}$

Respecto a la persuasión (movere), el bogotano solo consigna que su lugar es «el fin de cada concepto», de cada «discurso»y de cada «sermón». En el primer caso, se pueden usar sentencias en estilo magnílocuo, mientras que al final de todo el discurso y del mismo sermón está permitida cierta prolijidad.

\section{EL CONCEPTISMO}

Detengámonos ahora en el concepto y en los procesos que pautan su misión. El primero es el arte del tema:

son el tema y el lugar fundamental dos alas que, unidas entre sí, alivian al que sabe y al que no, lo entorpecen más. [...] Digo que si no quieres seguir lugar fundamental has de elegir una cláusula que te sirva de tema; será mejor mientras fuere más breve y concisa. [...] Lo segundo: se ha de mover y levantar una dificultad del mismo tema, darle la solución y de la solución formar la materia o intento de todo el sermón. Lo tercero: este mismo tema [...] dividir en tres partes. [...] Lo cuarto: en el principio y cabeza de cada discurso, se debe proponer la parte del tema que le toca con su dificultad levantada de esa parte dividida del tema y su proposición nacida de la solución para que el auditorio vaya viendo con claridad y distinción los intentos. [...] Lo quinto: al fin de cada discurso se debe probar confirmando su intento con el mismo tema. [...] Si todas las veces no pudieres hacer esto (que es dificultoso), estás obligado a hacer la última prueba con algún otro reparo del Evangelio, que también es gala y si, tal vez, por la trabazón de los conceptos te conviniere anticipar la prueba del Evangelio, harás lo que te conviene, ayudándote de la invención, disposición y fantasía. ${ }^{128}$

${ }_{125}$ Ibidem, fol. 144.

126 Véase P. Tanganelli, «"En la gloria en donde el lenguaje es ver”», cit.

127 V. de Céspedes, op. cit., p. 164.

128 M. de Velasco, op. cit., fol. 156. 
Del «tema» derivan las «proposiciones». Otro asunto conflictivo respecto a los modelos de Velasco: tanto el directo (Ormaza) como el ignoto (Céspedes). Pérez de Ledesma se había despachado contra el uso de «porqués», o sea, contra «la dificultad para establecer dónde acaba el "reparo" y dónde comienza el "concepto", que suelen originarse y / o desembocan en los lugares». ${ }^{129}$ Dicho reparo -que Velasco no cita como tal, aunque lo maldiga- consiste en una duda que levanta el predicador sobre algún pasaje de las Escrituras. El objetivo no es otro que solucionarla con la agudeza del ingenio. Pues bien, las saetas de Ormaza contra los que abusan de esta técnica son las más severas de su libro. Entre otras cosas porque sospecha que un buen número de erótesis lindan con la perogrullada: «Digo, pues, que aun en lo que necesita de prueba para reprehensible amontonar tantas, como vemos comúnmente: con una buena me contento aun en la más arrojada paradoja, cuanto más en los asuntos que debían suponerse, más que probarse». ${ }^{130}$

Velasco suscribe esta lección, acentuando un detalle del todo curioso que no figura en la obra del jesuita aragonés y tampoco en la del nieto del Brocense:

No se excusa este defecto de «porqué» en las proposiciones por el disimulo artificioso y traza grande con que se forman; pues con mucho ingenio y arte mayor (dicen) se parte el «por-qué» en dos distintas líneas, dejando pendiente en el fin de la una el «Por-» y empezando a formar la proposición en la otra siguiente con el «qué». [...] Lo que se quita en la forma de las proposiciones no es el «qué», ni el «porqué» $[. .$.$] sino el que a título de «porqué» se formen de nada. { }^{131}$

Céspedes había adelantado la objeción del bogotano, pues lo que disgustaba al autor de Trece por docena no era la técnica de reparos y porqués («Azote III»), por otra parte eficaz desde una perspectiva lógica, sino que se usaran fuera de lugar. Por tanto, no condena los reparos como fuente de agudeza. Lo censurable es su demasía, cuando no superan el umbral de la hojarasca. Escribe el pucelano: «si el porqué se repite sin qué ni para qué, sin decir más en la segunda pregunta que en la primera, ya he dicho que a todos nos enfada porque tenemos muy bonico gusto, pero si la pregunta que en la primera va apretándose con dificultades nuevas, y todas más agudas y más vivas, ¿por qué te ha de cansar?». ${ }^{132}$ Además, «concluye, lapidario, que se trata de mucho más que un simple «porqué», pues «apenas hay agudeza sin "porqué"» (III, 27). ${ }^{133}$

\footnotetext{
129 F. Cerdan y J. E. Laplana, op. cit., p. 39. No soslayemos que Céspedes había escrito que el «estilo conceptuoso» no existe (azote VI), mientras, en un alarde de ligereza, dedica el VII («Por lo que dice de los conceptos») a defender los «conceptos» de las censuras de su contrincante. Véase V. de Céspedes, op. cit., p. 168.

130 G. Pérez de Ledesma, op. cit., p. 148.

131 M. de Velasco, op. cit., fols. 158 y 160.

132 V. de Céspedes, op. cit., p. 108.

133 F. Cerdan y J. E. Laplana, op. cit., p. 46.
} 
Velasco sumará un detalle a esta polémica: aun confesando que Ormaza supo notar la vacuidad de los conceptillos basados en los «porqués», no planteó, sin embargo, una alternativa consistente. Es decir, las impugnaciones de Pérez de Ledesma le resultan epidérmicas, pues las correcciones que opone al «porqué» se concretan en remplazarlo -no en suprimirlo- por una quaestio similar. Cierto que de esta forma el Censor piensa que confiere variedad al estilo de los discursos, pero no a su estructura -es un mero conectivo- y tampoco a los conceptos tal como los define Velasco. Leamos un párrafo del Arte de sermones: «El «Censurador de la elocuencia» [...] fue claro para notar; y para enseñar se metió a confuso pudiendo notar el "porqué". De los conceptos para que su petición se evitase (que es lo que enfada), poniendo en su lugar: “¿Cómo puede ser?" “¿Cuál es la causa?” “¿Con qué razón?”».134

Si lo cotejamos con el «Azote III», crecen las analogías con Céspedes. Para el clérigo vallisoletano lo esencial no es si se usa el «porqué» u otro interrogante, sino el lustre de la réplica:

Las respuestas de las dudas unas son ordinarias y sin misterio particular, fáciles y de poco fuste; estas o no se soliciten dudando, o sea la duda remisa y sin instancia. [...] Otras respuestas hay misteriosas, difíciles, peregrinas y hermosísimas, y estas son como damas de muchas prendas, que merecen muy bien que las pregunten y las conquisten y los porqués las galanteen». ${ }^{135}$

Veamos otro ejemplo incluso más cercano a Velasco: «Al primer lugar de la salutación del ángel entra luego: “QQué es esto?” “¿Cuatro veces llena de Dios?”. ¿Esta es pregunta, señor mío? Dirá que no, porque tuvo cuidado de no nombrar el maldito "porqué"».136

El retórico de Santa Fe penetra que «los conceptos son el modo de probar las proposiciones». ${ }^{137} \mathrm{Y}$ dado que la lógica y la dispositio permitirán que asimilemos la conción e incluso sus agudezas, sugiere que «para formar el concepto se ha de mover primero la dificultad del pasaje tomado de la Escritura». Lo que equivale a decir que las alegorías y los tropos para enlucir, aclarar («la mayor de sus galas») u oscurecer los textos sagrados solo intervienen en una segunda fase y no hay que calificarlos -por lo que toca al sermón, otro cantar sería la lírica- como raíz de la agudeza, sino un adorno posterior. Por ello opta por los episodios más trillados de la Escritura, ya que, gracias a su popularidad, dificultan la tarea del ingenio, que debe esforzarse por sacar partido a un capítulo conocidísimo. Al decir de Velasco, «para que los conceptos sean vivos, solo

\footnotetext{
134 M. de Velasco, op. cit., fol. 179.

135 V. de Céspedes, op. cit., p. 109.

136 Ibidem, p. 111.

137 M. de Velasco, op. cit., p. 164.
} 
se requiere que salgan a propósito, y al primer golpe, sin embarazos ni estorbos». ${ }^{138} \mathrm{La}$ claridad los separa de los demás tropos, epifonemas, sentencias, etc., cuya misión se reduce a abrigarlos. ${ }^{139}$ Porque una simple sarta de conceptos es el mayor abismo del discurso. Más aún: la claridad expositiva requiere tiempo para digerirla. Si elidiéramos esos tropos protectores, caeríamos en el error de enjaretarlos uno tras otro, sin pausa ni medida. Y la claridad se convertiría entonces en tiniebla.

Particular que no impide a Velasco separarse aquí de san Agustín. Basta una rápida ojeada al capitulillo 6 del libro II del genio de Hipona para confirmar su apología y hasta su patrocinio de la oscuridad en los textos sagrados, a fin de que sus profundos conocimientos permanezcan alejados del vulgo. Ahora bien, Velasco tan solo citó la Doctrina cristiana, sin más pormenores; y Ormaza, de pasada, remitió a los tres últimos capítulos del mismo libro, donde el santo recomienda que se lean «los Étnicos y Profanos autores». De ahí que yo piense que la cita del «Prólogo» del Arte de sermones es un mero tópico sin trascendencia.

El esfuerzo por resumir su teoría sobre los conceptos redunda en tres ideas que guardan parentesco con las de otros barrocos: 1) en primer término aparecen el «tema» y el «lugar» evangélicos; 2) ambos se ramifican en «proposiciones»; 3) los «conceptos» son la forma de probar las proposiciones, sirviéndose de la imaginación, la disposición y la fantasía, atributos citados tanto en las Oraciones evangélicas de Paravicino como en la Censura. Y una acotación: aunque no me detengo sobre Gracián, para no convertir este trabajo en un laberinto de citas, la lectura de Velasco no dista mucho de la Agudeza, pues el autor del Criticón también describe tres elementos (o fases) enlazados: 1) el ingenio, avalado tanto por Ormaza como por Velasco, es una dimensión superior de entendimiento humano regida por la sutileza del pensar; 2) la fuerza del ingenio para crear correspondencias y engendrar conceptos es la agudeza; y 3) el concepto se define como el pensamiento formado con tales correspondencias. ${ }^{140}$

Así, el «concepto» de Velasco parece beneficiarse de varios de los sentidos con los que se ha venido usando el término: 1) pensamiento profundo o agudo; y 2) modo peculiar de metáfora. Si Pellegrino (1598), a partir de Tasso, sostenía que el «concepto» -para él sinónimo de «agudeza»- es el «ánima» que vivifica el verso, y Mazzeo atribuyó la formulación de esta agudeza conceptista a Giordano Bruno, cuya

\section{Ibidem, p. 165.}

139 Velasco se desvía aquí de las críticas de Céspedes al Ormaza. Para el nieto del Broncense, «Pérez de Ledesma» es el «conceptuador»; y se ríe docenas de veces del «estilo que llaman conceptuoso, tan idolatrado por el «Censor», pero asumido por el vallisoletano -erróneamente- como equívocos, retruécanos, alusiones y juegos de vocablos. Véase L. López Santos, op. cit., p. 359.

${ }^{140}$ Véase J. M. Ayala, op. cit., p. LXX. 
producción analiza como una "poética de correspondencias» basada en el principio de las analogías entre los elementos más dispares, ${ }^{141}$ Velasco lo desarrolla de forma bien distinta, próxima a la de Gracián. Para el colombiano lo que vivifica y anima el sermón son las proposiciones, mientras que los conceptos, de naturaleza ideológica, tienen la función de resolver unas premisas sólidamente fundadas. Se diría que son la consecuencia natural de aquellas.

No comparto los análisis generalistas de estos sustantivos en feliz alianza. Quizá haya que exigir, a estas alturas, que se precise con tiento, en cada uno de los autores, qué se entiende por «concepto», «agudeza» e «ingenio», superando el retrato a vuela pluma de Herrero cuando denunciaba que en la oratoria sagrada no había una definición explícita de los «conceptos»:

se deja entender que se trata de una «frase breve de contenido profundo y forma ingeniosa». Esta frase feliz, o concepto, una veces es la chispa de un ingenio rápido y sutil; otras es el resultado de una elaboración consciente; otras es la salida a todo un proceso dialéctico que parte de una proposición (aun cuando no faltan autores que llaman concepto precisamente a esta proposición o tesis); finalmente, para muchos oradores los lugares o citas de la Escritura son los verdaderos y únicos conceptos. Podría resumirse la cuestión diciendo que unos oradores tienen una idea lógica y estética en mayor o menor grado del concepto; otros una idea dialéctica, y otros, una idea escrituraria. ${ }^{142}$

Ha de quedar claro que si Ormaza los considera semejantes a esa «chispa del ingenio» de la que hablara Herrero, Céspedes los lee más bien como un trasunto de los lugares o citas bíblicas y Martín de Velasco se enrola entre quienes, partidarios de una oratoria dialéctica, los asocian con los medios para resolver las proposiciones. ${ }^{143}$ Falta mucho, como digo, para aislar sus matices y fronteras entre los predicadores. Por eso resulta de veras valioso el artículo de Mercedes Blanco, pues concluye que al teorizar sobre «lugares», «reparos»y «conceptos» hay que disipar tanto el ruido como la confusión de muchas retóricas:

si «lugares» $\mathrm{y}$ «reparos» pueden funcionar en ciertos contextos como términos intercambiables es porque el reparo es una forma construida con los materiales aportados por los lugares de la Escritura. [...] Si «reparo» y «concepto» pueden en ocasiones confundirse es porque, en la práctica, el reparo constituye la forma más característica que adopta el concepto en el sermón. Dicho de de otro modo, la denominación «reparo» es con respecto al «concepto» una sinécdoque de la

\footnotetext{
${ }_{141}$ Véanse A. Collard, op. cit., pp. 26-27, y J. A. Mazzeo, «A Critique of Some Modern Theories of Metaphysical Poetry», reimpreso en W. R. Keast, Seventeenth Century English Poetry, New York, 1962, pp. 63-74.

142 F. Herrero Salgado, La oratoria, pp. 443-444.

143 A. de Bondía, op. cit., fol. 114, expone que «toda la elocuencia no consiste sino en dos cosas, que son palabras y conceptos formados por esas mismas palabras con vida de sentencias».
} 
especie por el género, y el «lugar» es con respecto al «reparo» una sinécdoque de la materia por la forma. ${ }^{144}$

Como explica Blanco, hay que acudir a Gracián para clasificar la «agudeza de reparo», ya que se trata del único autor que se molesta en definir la jerga que todos utilizan -me permito añadir que también Velasco, si bien con menos brillantez-. Y sugiere una tesis que ilumina el planteamiento de Céspedes sobre el asunto:

se parte de una conexión «entre el sujeto y sus adjuntos» o entre los adjuntos de un mismo sujeto, que es un datum y no un constructum, conexión establecida en una proposición narrativa, casi siempre de tipo histórico. Si se nos permite inventar un ejemplo, sean las conexiones entre «César» y «Bruto», "César» y «Senado», «matar a César» y «Senado», construidas en el enunciado: «Bruto mató a César en el Senado». En una primera etapa, se levanta el misterio. [...] Levantaremos uno si decimos «¿Por qué el asesino de César fue Bruto precisamente y no otro cualquiera?». «¿Por qué fue muerto César precisamente en el Senado y no en otro lugar?». ${ }^{145}$

Sin nombrarlos, descubrimos que Velasco sí escribió sobre los reparos cuando -como Ormaza- censura a los antiguos la técnica de los «porqués». Dichos «porqués» serían la fase previa de la «solución», que, como sostuvo Gracián y asume el bogotano, ya es en sí misma un «concepto»; por más que el religioso de Santa Fe no se esmere en glosarlos con el tino de Gracián en la Agudeza: conceptos por correspondencia, por improporción y disonancia, por semejanza, etc.

Otro detalle nada baladí: Velasco no habla de los «conceptos predicables», llamados por los italianos concetti napolitani, a través de los cuales el orador enseñaba argumentos ingeniosos que, con admirables y metafóricas reflexiones sobre la Escritura y los Santos Padres, exponían la doctrina cristiana. Un nuevo maná retórico, tan grato para los doctos como para los ignorantes. ${ }^{146}$

Empero, al sondear la clasificación de Tesauro, que divide la hechura de esos conceptos en «tema», «argumento ingenioso», «dificultad, «solución», «aplicación»y «autoridad», atisbamos el rastro de los dos primeros en lo que el colombiano llama aquí «tema»; así como de la dificultad, metamorfoseada ahora en «proposición»; y de la solución, aplicación y autoridad, que el fraile novohispano identifica con subdivisiones o partes de lo que él denomina «concepto».

No es el único problema: las triparticiones en las que organiza sus capítulos implican que, si no respetamos los eslabones de su cadena, se rompería el decoro entre la creación, la interrogación y la solución del concepto, que tiene algo de enigma, y

\footnotetext{
144 M. Blanco, op. cit., pp. 125-126.

145 Ibidem, p. 127.

146 Véase F. Herrero Salgado, La oratoria, pp. 445-446.
} 
el estilo con el que los despliega. Se trata, pues, de un proceso elocutivo, pero antes incluso dispositivo y, en último término, cognoscitivo. Solo así se comprende que la forma del concepto se fraccione en tres partes: principio, medio y fin:

El principio es desde la introducción hasta ponerse sobre la dificultad y levantar la mediación es todo con aquel medio, que se interpone desde que se levanta la dificultad hasta que se le da la solución, y la parte última es desde la solución hasta la transición del otro concepto que se sigue. [...] Y así la introducción se hace con estilo remiso, agudo y, hablando de sentencia, en la mediación tiene su proprio trono el estilo medio claro y el adornado elegante y numeroso. Desde la solución hasta acabar con el concepto, es el lugar del estilo grande, con el cual se va dando más lucimiento al concepto. ${ }^{147}$

Según Velasco, todo el arte de hacer buenos conceptos descansa en la buena disposición de las premisas. Siempre con estilo remiso, pero no de forma tan seca que espante a los oyentes; esto es, entreverándolas con notas de fantasía. Para ello es básico distinguir entre las nociones de «acomodación» y «prueba», así como el orden en que estas se emplean: «no confundas la acomodación con la prueba, ni la prueba con la acomodación. Porque la prueba sale en la solución, y después de la solución se hace la acomodación, reduciendo, ponderando, persuadiendo». ${ }^{148}$ Una de sus faltas teóricas es que, si bien define cuáles son los conceptos que piden pocas prevenciones, los muy breves de la prueba del Evangelio y los del lugar, no apunta qué criterios ha seguido para jerarquizar los otros. En la medida en que afirma que los conceptos del discurso sirven como «ilustración»-entiéndase "serie", variando el estilo justo en la sentencia que los anuda-.

Lo axiomático del Arte de sermones es que todo concepto se compone de tres cosas: «texto», «autoridad»y «razón». El texto se toma de la Sagrada Escritura, la autoridad de los Santos -Velasco se suma aquí a los antiguos- y la razón del ingenio del predicador. Con otras palabras: el texto levanta la dificultad, la autoridad funda las premisas y la razón las resuelve. ${ }^{149} \mathrm{El}$ problema es que más tarde vemos fundidas las ideas de razón -tercera parte, y la más ormaziana, de su pensamiento- y concepto, que, según hemos visto, era un todo: «la razón, que es concepto, nace impelida con la fuerza que la dan las premisas». ${ }^{150}$ Esta licencia quizá surja porque lo realmente misterioso y difícil no son las reglas que dictan cómo se forma un concepto. Ni siquiera sus partes. Casi iguales, de hecho, a las que proponen otras plumas barrocas con las que aún no se ha vinculado a los predicadores. Por ejemplo, Jáuregui discurría de forma parecida sobre los conceptos en su Discurso poético (1624). A su juicio, cualquier obra

\footnotetext{
147 M. de Velasco, op. cit., fol. 167.

148 Ibidem, fol. 172.

149 Ibidem, fol. 173.

150 Ibidem, fol. 174.
} 
es un compendio de «alma, cuerpo y adorno», equivalentes al tema y las proposiciones (“alma”) y al concepto ("cuerpo") de Velasco.

Para el bogotano el quid del discurso reside -de nuevo la dispositio- en la unión de sus conceptos, «porque los rectóricos antiguos y modernos no descubrieron bien este primor». ${ }^{151} \mathrm{Y}$ no tarda (discurso 54) en aferrarse a Gracián, que había observado esta dificultad: «adonde dice: "lo más arduo y primoroso de estos compuestos de ingenio falta por comprehender: que es la unión entre los asuntos y conceptos parciales. El arte de hallarla sería superlativo primor de la sutileza" ». ${ }^{152}$ Con la voluntad de rubricar no una Agudeza y arte de ingenio, sino un «arte de agudeza», Velasco traza con mimo las reglas de la creación y articulación de los conceptos. Aunque, curiosamente, la palabra «agudeza» no desfile por su texto y haya que suponerla o asociarla con los mismos conceptos. A pesar de su longitud, voy a reproducirlas, pues contribuyen a nuestro propósito:

La primera: después que hayas hallando algunos conceptos para el discurso, te valdrás de la disposición, y con ella de la hipótesis, que es suposición, viendo y considerando cuál concepto de los que tienes, con su doctrina de suposición para todos los otros, y a eso dispondrás en el primer lugar. Luego, de los que quedan verás si hay alguno que también suponga para el tercero, y lo pondrás por segundo. De esta suerte llevarán todos orden y conexión verbosa y de substancia. [...]

La segunda: te valdrás de la alusión [...], de manera que se aludan unos conceptos a otros. Y la mejor alusión es que el concepto aluda al Evangelio o al lugar fundamental. [...]

La tercera: si los conceptos, o alguno de ellos, fueren contextuales con el tema o con el lugar, resulta en el discurso gran correspondencia. $Y$ por esta causa se debe usar, fuera del tema, el lugar fundamental, para que haya más ocasión de que el concepto sea contextual y demás asonancia.

La cuarta: los conceptos que se hacen por antítesis o contraposición son muy buenos. Porque aunque parece que disuenan, después de concertados hacen mejor armonía. Y así pueden hacer los conceptos contrapuestos al tema o al lugar fundamental. [...]

Hay algunos conceptos (y sea la quinta regla) que, pensados bien, pueden servir de reducción o de recopilación de los antecedentes. Estos sirven para la clave del discurso y adonde relucen más es en el fin de todo el sermón. [...]

De hacer lo contrario, salen los discursos -como dice Gracián- discursos amorcillados, y los conceptos de alforja ${ }^{153}$.

Lo que nos interesa es que Velasco considera que «es la armonía en el discurso el Jordán de los conceptos». ${ }^{154} \mathrm{Y}$ también que parece identificar el término con el más

151 Ibidem, fol. 177.

152 Ibidem, fol. 177.

153 Ibidem, 180-182.

154 Ibidem, fol. 183. 
vago -al tiempo que ilustrativo- de «idea». Así, las ideas son el alma de los sermones. Máxima que supone otro cintarazo contra Pérez de Ledesma y permite extraer una distinción exclusiva del Arte del colombiano. Velasco indica que el «estilo de historia», o sea, los discursos que relatan la vida de una persona desde la cuna a la sepultura, poco tienen que ver con la «idea». Por la simple causa de que el hilo cronológico se trenza con más nitidez que en el resto, pero carece de Arte, pues suelen incurrir en la mayor de las pesadumbres.

Pienso que este cisma entre «sermón historial»y «sermón conceptual» recubre una crítica a la moda ormaziana de utilizar pinturas y descripciones en los suyos, donde, como sabemos, no están exiliados los conceptos, pero que a Velasco le resultan tediosas y poco «artísticas». Lo repite con voces semejantes en el capitulillo XXVI, donde afea el uso de «pinturas, postillas, perífrasis, paréntesis, dichos, picazones, ponderaciones y epifonemas». ${ }^{155}$ Azote que nace de una cierta postura aticista: «no es Arte de hablar mucho, sino bien; y habla bien quien tiene Arte y disciplina para castigar el ímpetu natural». ${ }^{156}$ Ímpetu y disciplina fijados en una metáfora que representa otro dardo contra los nuevos «predicadores de afluencia». Velasco opina que los que prescinden de «muletas», esto es, de autoridades y citas, no han reparado en que «hay muletas en los templos que hablan de milagro, y que los torrentes de los arroyos crecidos, si llevan mucha agua, es turbia y llena toda de broza». ${ }^{157}$ Leamos la premática con la que cierra este debate:

Son muchas las utilidades de predicar así los sermones. Lo primero, llevan forma; lo segundo, enseñan con su ejercicio a dispertar el ingenio y que obre por sí, cavando, profundando y hallando admirables materias y modos; lo tercero, facilita la memoria; [...] la cuarta, alivian el ejercicio de predicar, pues en una hora con tu ingenio y este arte hallarás para predicar de un mismo Sancto más de cien materias; [...] lo quinto, harás los sermones con mucha brevedad y presteza; lo sexto, recibirá el púlpito la majestad y respecto que el otro modo de predicar le había quitado y perdido. Lo séptimo, se sabrá quien hace los sermones y no habrá tantos atrevidos; lo octavo, harán los sermones los que saben y fueren entendidos; lo nono, sacará más doctrina y menos flores, saliendo enseñado y corregido, que es el intento principal; lo décimo, con estas divisiones y su orden se predica más claro, tanto que los más pobrecitos y simples del auditorio entienden lo que el predicador les dice y sacan más provecho de su doctrina. Lo undécimo, los más entendidos del auditorio estarán más a pique de convertirse, que si no se usan estas conversiones es porque oyen siempre sermones floreados, indigestos y pesados. ${ }^{158}$

Sentada la utilidad de su Arte, por cuyas páginas se filtra de nuevo la vanidad al declarar que su lectura facultará al novel orador para tomar las riendas del oficio

\footnotetext{
155 Ibidem, fol. 209.

156 Ibidem, fol. 197.

157 Ibidem, fol. 196.

158 Ibidem, fols. 201-202.
} 
en apenas una hora, añade una serie de ejemplos prácticos -tres sobre «La división del tema en el Sermón de la conversión de Santa María Magdalena» y uno acerca de «La división del tema Ecce Mulier Quae Erat para sacar de él tres proposiciones para tres discursos»- que ratifica su posición equidistante en la querelle Ormaza vs. Céspedes, pues el libro de Pérez de Ledesma terminaba igual, según hemos notado.

\section{Arte de Deleitar}

Quisiera dedicar unas líneas a otro de sus capítulos: el «Arte de deleitar» (ף XXVII). Velasco hace bandera de una predicación ex visu y subordinada a la ex auditu. Con un matiz: sabedor de que «más se deleitan los hombres viendo las cosas presentes o representadas que oyendo las referidas», ${ }^{159}$ no anula su favoritismo por un sermón con elementos visivos, aunque sin la utilería (calaveras, crucifijos, etc.) de otros clérigos de aquel tiempo. El colombiano arbitra que el pintor ha de serlo, pero no parecerlo a ojos de su auditorio: «mientras no estamos en la gloria en donde el lenguaje es ver, será fuerza que lo que intentamos acá dar a ver lo signifiquemos con las palabras a los oídos, para que deste sentido pase a la fantasma y representación de las cosas, en donde estas se deleitan y no las palabras». ${ }^{160}$ De estas frases a las pinturas imaginarias de Ormaza solo hay un paso. Con lo que aminora o deroga el chuzo que le cayó al jesuita cuando Velasco discurría sobre los aprendices en el púlpito. Por otro lado, somete los verba al dominio de la res:

Las palabras no deleitan, sino las cosas significadas por medio de las palabras. [...] Debe el predicador cuando nota o pinta hacer la notación o pintura para que se vea la cosa pintada, no lo mano que la pinta. Ha de saber pintar pero no parecer pintor, diciendo las cosas como se deben en este estilo. ${ }^{161}$

Una pauta que se ajusta a las de la Retórica sagrada de Ameyugo. ${ }^{162}$ Abundo, no obstante, en su despego hacia los que atacaron las cronografías; y más exactamente las dirigidas a los oídos, como el jesuita Jarque, quien señalaba en El Orador cristiano (1657) que «otros predican a los oídos, gastando prosa y tiempo en describir jardines, y primaveras, batallas y tempestades de mar, risas de alba y nacimientos de Sol». ${ }^{163}$ Tanto si juzgamos válidas dichas cronografías como si no, la obra de Velasco es una aleación de las tesis de Ormaza y las de los antiguos. Por más que a veces parezca la jugada de un tahúr que oculta dos naipes distintos en su bocamanga. Lo raro es que

\footnotetext{
159 Ibidem, fol. 210.

160 Ibidem, fol. 210.

161 Ibidem, fol. 211.

162 Véase P. Tanganelli, La descrizione, p. 73.

163 J. A. Jarque, El Orador Christiano sobre el Miserere. Sacras invectivas contra los vicios, Zaragoza, M. de Luna, 1657, I, fol. 355.
} 

-como consta en una de las pullas de Céspedes a Pérez de Ledesma- haya continuado «agazapada» hasta hoy y «no la conociera ni la madre que la parió». 164

Así y todo, un detalle justifica este Arte de sermones respecto a la Censura, el Triunfo de la verdad y Trece por docena. Los dos últimos libros nacieron -como el Antídoto contra la pestilente poesía de las Soledades (1616), de Jáuregui, o el Examen del Antídoto (1617), del Abad de Rute, «censura» y «azote» contra y a favor de Góngora, por otro lado, con los que podrían medirse los de Ormaza, Bondía y Céspedes en el campo oratorio- para castigar a un treintañero más que díscolo. Son «exámenes o antídotos citantes»; se pliegan a lo que escribió Pérez de Ledesma, ya sea para aplaudirlo, comentarlo o reírse de él.

El Arte de Velasco habría que clasificarlo, en cambio, como un tratado que, según el precepto ormaziano, huye de las autoridades explícitas. Una cuenta tardía del rosario de ingenios que se batieron el cobre por y con el Censor. Pero engarzado a él de forma ancilar. Solo en ciertos capítulos. Incluso diría que es tan poco citante como la Censura de la elocuencia. El bogotano renunció a ofrecernos un vejamen del tipo de Bondía o el nieto del Brocense, para extractar, a lo largo de doscientos folios, quince o veinte párrafos del aragonés.

$\mathrm{Su}$ objetivo es otro. El fraile de Santa Fe supo cribar y digerir las conciones de Pérez de Ledesma, pero también las de otras sotanas, con vistas a un manual más sistemático, pero también más plomizo y a ras de suelo, que los gestados por la Compañía. Sin la sulfúrica gracia de Céspedes. De espaldas a la «puerilidad» con la que el pucelano apostrofaba a Ormaza. Tampoco cataremos ya las sales del nieto del Brocense, genuino maestro del mote («censurilla», «dómine censurante, «zorrero») y del doble sentido, aunque en la cumbre de la ironía -como un Quevedo monacalniegue el estilo conceptuoso.

Al desterrar de su obra cuentos como el de «Roquillo de Zaragoza» y triunfos léxicos del calibre de «hazañero exclamador», «estilico columpiado», «afeminados que se rizan», «ladronicio intolerable» o «clausulitas de sompesete», Velasco no solo enterró un hacha de guerra que no le pertenecía, sino que, con un gesto de humildad inédito en Pérez de Ledesma, se decidió a bajar medio punto los ojos y lo culto de las letras para levantarlos de nuevo hacia el culto de Dios.

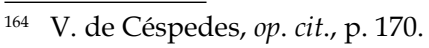

